
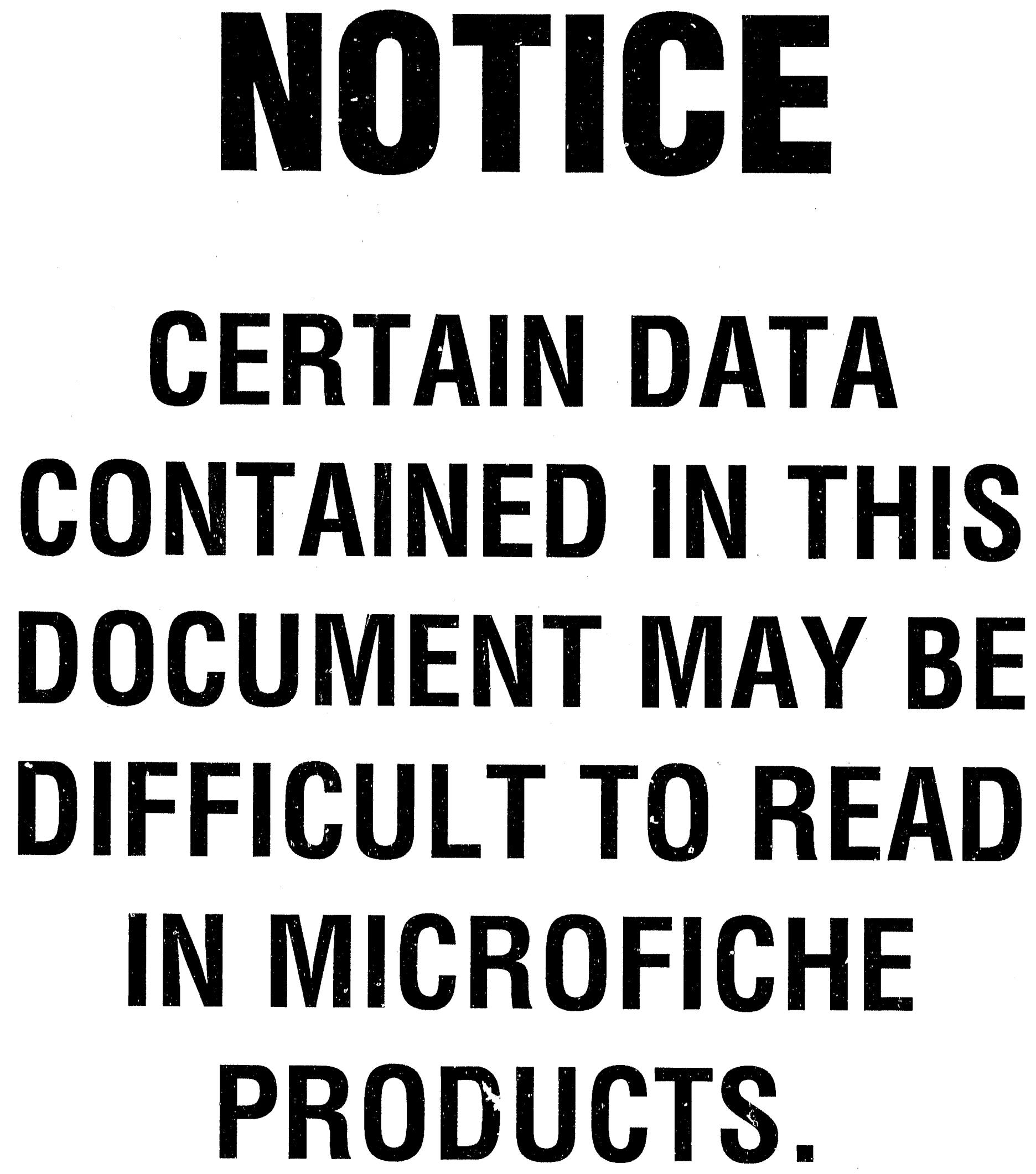


\section{MOISTURE CONTENTS AND UNSATURATED CONDITIONS IN UMTRA PROJECT RADON BARRIERS}

January 1989

\section{DISCLAIMER}

This report was prepared as an account of work sponsored by an agency of the United States Government. Neither the United States Government nor any agency thereof, nor any of their employees, makes any wrirranty, express or implied, or assumes any legal liability or responsibility for the accuracy, completeness, cr usefulness of any information, apparatus, product, or process disclosed, or represents that its use would not infringe privately owned rights. Reference herein to any specific commercial product, process, or service by trade name, trademark, mainfacturer, or otherwise does not necessarily constitute or imply its endorsement, recommendation, or favoring by the United States Government or any agency thereof. The views and opinions of authors expressed herein do not necessarily state or reflect those of the United States Government or any agency thereof.

\section{U.S. Department of Energy UMTRA Project Office Albuquerque Operations office A7buquerque, New Mexico}




\section{MOISTURE CONTENTS AND UNSATURATED \\ CONDITIONS IN UMTRA PROJECT \\ RADON BARRIERS}

ABSTRACT

A typical Uranium Mill Tailings Remedial Action (UMTRA) Project disposal facility consists of uranium tailings and other contaminated materials covered by a three to six foot thick radon barrier and six inches of filter sand, overlain by one foot of erosion-protection riprap. To comply with the proposed U.S. Environmental Protection Agency groundwater protection standards applicable to the UMTRA Project (40 CFR 192), groundwater concentration limits of hazardous constituents cannot be exceeded at the point of compliance, which is the downgradient limit of the waste management area. The typical radon barrier has a saturated hydraulic conductivity of approximately $1 \times 10^{-7}$ centimeters per second $(\mathrm{cm} / \mathrm{s})$. Operational hydraulic conductivities, however, may be several orders of magnitude lower if the radon barrier is unsaturated. Long-term seepage rates from a disposal facility with an unsaturated radon barrier may permit the concentration limits to be met at the point of compliance. Field studies were undertaken to measure the percent saturation and the relation of percent saturation to soil tension, and to predict the hydraulic conductivity as a function of percent saturation in radon barriers at three UMTRA Project disposal facilities that have been completed for up to two years. The disposal facility at Shiprock, New Mexico, was instrumented to continuously monitor soil tension and moisture contents. Results of the field studies indicate that moisture contents in the radon barriers range from 82 to 86 percent saturation, which is slightly less than the placement moisture content during construction. Seepage rates through the radon barrier calculated using unsaturated hydraulic conductivities from soil core data and a hydraulic gradient of unity are approximately $1 \times 10^{-9} \mathrm{~cm} / \mathrm{s}$ or less.

It is qualitatively predictable that typical UMTRA Project covers will function similarly in similar climatic environments. Presently, typical covers have been completed at the Shiprock, Clive, and Burrell sites, and they are planned or under construction at the Ambrosia Lake, Green River, Lakeview, Mexican Hat, Slick Rock, and Tuba City sites. With the exception of Burrell and Lakeview, all of these sites are in semiarid regions and have comparable precipitation and potential evaporation. The low unsaturated hydraulic conductivity of the radon barrier prevents significant infiltration of moisture during periods of saturation of the filter layer. Any moisture that penetrates the upper portion of the radon barrier is held there until it is evaporated through the filter layer and the erosion protection riprap. This design prevents the radon barrier from becoming saturated and assures that the radon barriers in typical UMTRA Project disposal facilities will operate at unsaturated hydraulic conductivities of $1 \times 10^{-9} \mathrm{~cm} / \mathrm{s}$ or less. The design of the typical UMTRA Project covers can be further optimized to assure that the radon barriers operate under unsaturated conditions. 


\section{Section}

Page

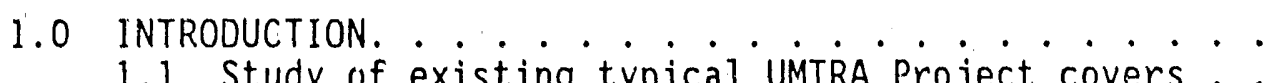

1.1 Study of existing typical UMTRA Project covers...
1.2. Methods and instrumentation. . . . .

1

2.0 RESULTS FROM THE STUDY OF SHIPROCK, CLIVE, AND

BURRELL ...................... . . . 7

3.0 MOISTURE DATA FROM LONG-ESTABLISHED SMALL DAMS. . . . 19

4.0 EXPECTED PERFORMANCE OF TYPICAL COVERS AT SEMIARID SITES . . . . . . . . . . . . . . . . . 22

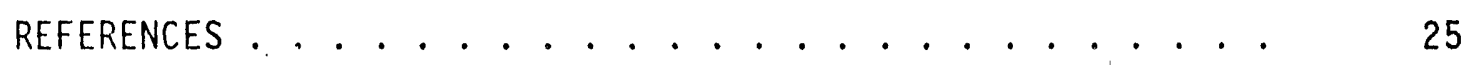

ATTACHMENT A - SOIL CHARACTERISTICS DATA FOR THE RADON BARRIERS AT SHIPROCK, CLIVE, AND BURRELL 
1.1 Typical UMTRA Project disposal facility........ 2

1.2 Borehole and instrument station locations at the Shiprock disposal facility.........

1.3 Instrumentation at Station I on the Shiprock disposal facility. . . . . . . . . . .

2.1 Profiles of percent saturation versus depth

from core samples at Shiprock and Clive . . . . . . .

2.2 Profiles of percent saturation versus depth

from core samples at Burre11. . . . . . . . . .

2.3 Moisture content profiles for Station 205 on June 30, August 10, and September 29, 1988, determined by neutron probe logging . . . . . . . . .

2.4 Soil tension measured at the top and bottom of the filter layer at Shiprock ............

2.5. Soil tension measured at depths of 3 and 6 inches into the radon barrier at Shiprock .........

2.6 Soil tension measured at depths of 12 and 18 inches into the radon barrier at Shiprock. . . . . . . . . .

2.7 Soil tension measured at depths of 24 and 48 inches into the radon barrier at Shiprock. . . . . . . . . .

2.8 Relation of percent saturation to soil tension in the radon barrier at the Shiprock disposal facility. . ..............

2.9 Relation of hydraulic conductivity to percent saturation for the Shiprock and Clive radon barriers. .

3.1 Profiles of percent saturation for four earth-fill dams ................

TABLE

Table

4.1 Site climatological characterization data...... 


\section{C INTRODUCTION}

Compliance with the proposed U.S. Environmental Protection Agency (EPA) groundwater protection standards (40 CFR 192) at most Uranium Mi11 Tailings Remedial Action (UMTRA) Project disposal facilities involves demonstrating that seepage will not cause concentration limits to be exceeded at the point of compliance. The point of compliance is the downgradient limit of the waste management area. Such a demonstration usually involves calculating the seepage rate from the tailings disposal cell and modeling resultant concientrations of contaminants in groundwater.

A typical UMTRA Project disposal facility consists of uranium tailings and other contaminated materials covered by a three to six foot thick radon barrier and six inches of filter sand, overlain by one foot of erosion protection riprap (Figure 1.1). The typical radon barrier, especially one designed prior to the proposed EPA groundwater protection standards, has a saturated hydraulic conductivity of approximately $1 X$ $10^{-7}$ centimeters per second $(\mathrm{cm} / \mathrm{s})$. The filter layer usually consists of a sand with a hydraulic conductivity of 0.001 to $0.01 \mathrm{~cm} / \mathrm{s}$ and is designed to separate the erosion protection riprap from the radon barrier during construction, to protect the radon barrier from erosion, and to facilitate drainage off the radon barrier. During construction of the disposal cell, water is sometimes added to the tailings and radon barrier to achieve a design compaction and moisture contents.

Seepage rates through the radon barrier at a disposal facility are equal to the product of the hydraulic conductivity (a function of the moisture content) and the hydraulic gradient. If moisture contents in a homogeneous material are vertically uniform, the hydraulic gradient is unity. However, using the saturated hydraulic conductivity of $1 \times 10^{-7}$ $\mathrm{cm} / \mathrm{s}$ in the radon barrier for the purpose of calculating seepage rates is highly conservative and in some cases precludes demonstrating compliance with the concentration limits. Operational hydraulic conductivities of the radon barrier and long-term seepage rates from the disposal facility may be several orders of magnitude lower if the radon barrier is unsaturated.

A literature review was performed to determine if infiltration studies had been conducted on rock covers that were similar to the typical UMTRA Project covers. Because no full scale infiltration studies have been conducted on rock covers, investigations were initiated at three UMTRA Project sites where remediation of abandoned tailings piles has been completed under Title I of the Uranium Mill Tailings Radiation Control Act. The study was intended to provide a data set for predicting long-term performance of typical UMTRA Project covers in limiting infiltration into the underlying tailings. Soil cores were obtained from the Shiprock, New Mexico, Clive, Utah, and Burrell, Pennsylvania UMTRA Project sites to determine the percent saturation and unsaturated flow characteristics of the radon barrier. The Shiprock disposal facility was instrumented to continuously measure soil tension and moisture contents 


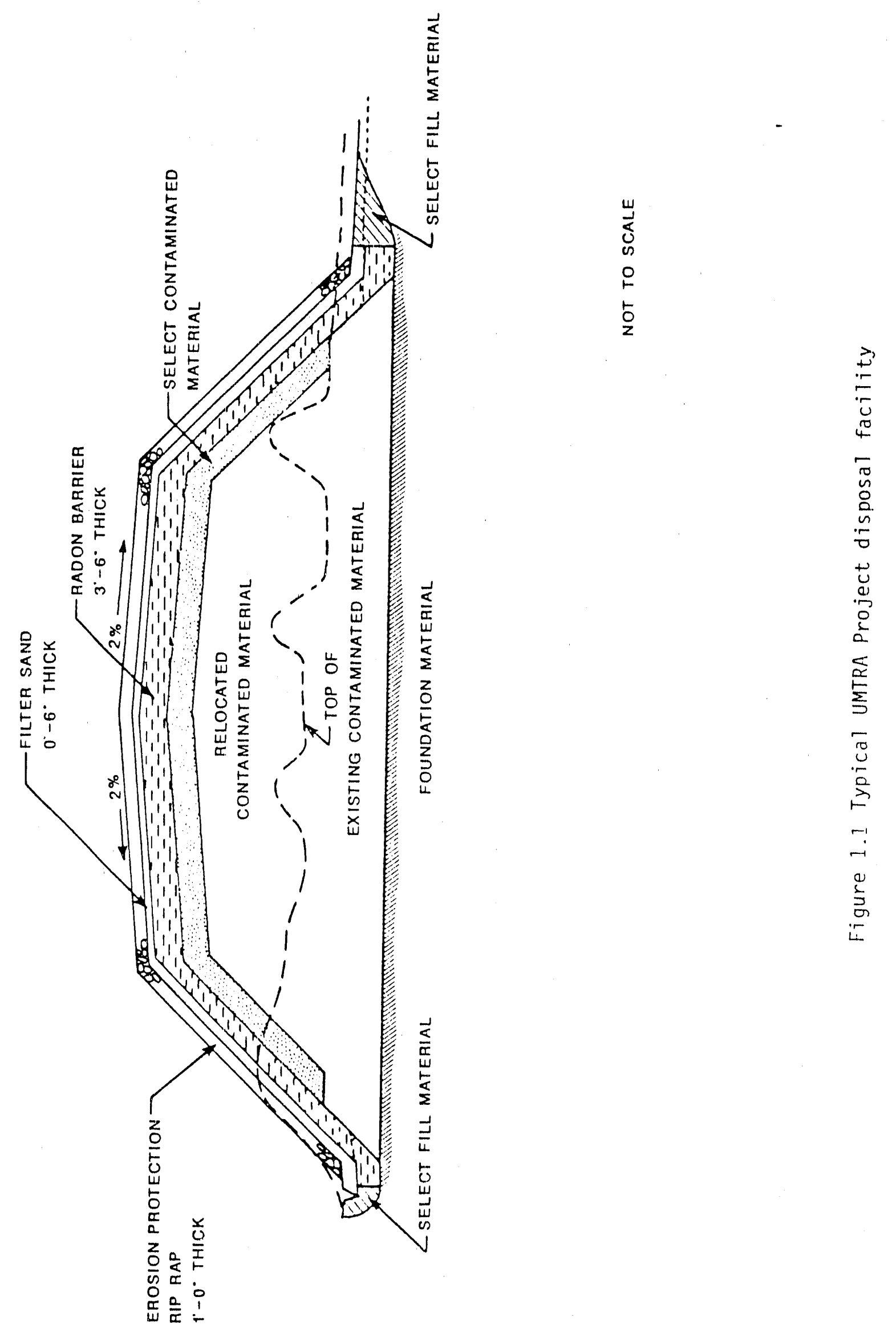


within the components of the cover. An attempt to provide a long-term perspective on the movement of moisture and changes in -the percent saturation within low hydraulic conductivity materials in arid climates was made by examining soil core data from several small dams in New Mexico.

\subsection{STUDY OF EXISTING TYPICAL UMTRA PROJECT COVERS}

Three previously constructed disposal facilities were selected for field studies of cover moisture conditions. The Shiprock (New Mexico) and Clive (Utah) disposal sites are in semiarid climates, with annual precipitations of approximately six inches and five inches, respectively. The Shiprock facility was completed more than two years ago, and clive is now at completion (though portions of the cover have been in place for more than a year). The Burrell (Pennsylvania) site has been completed for approximately one year and is located in a more humid climate where the average annual precipitation is approximately 44 inches. Each of these facilities has the typical cover, although their radon barriers vary in thickness from three feet at Burrell to seven feet at Shiprock and Clive.

\subsection{METHODS AND INSTRUMENTATION}

Samples of the radon barrier were collected at each site to determine the percent saturation and the relation of moisture content to soil tension, and to predict the relation of hydraulic conductivity to moisture content. The Shiprock disposal facility was instrumented with a weather station to measure climatic parameters, and with monitoring equipment to measure moisture contents, soil tensions, temperature, and heat flux in the different components of the cover. Borehole and instrument station locations on the Shiprock disposal facility are shown on Figure 1.2.

Soil borings at the Shiprock and Clive sites were performed using a hollow stem auger to collect samples of the radon barrier and uppermost tailings. Soil borings were advanced into the radon barrier at Burrell using a hand-driven California sampler. Boring locations were selected to provide information on the variability in percent saturation in the covers of the disposal facilities. Brass-ring samples were cullected at all sites, and a CME sampler was used to collect additional samples at Shiprock. Following drilling, all boreholes were backfilled with cuttings and grouted to ground surface. The soil samples were analyzed using ASTM methods for moisture content by weight, dry bulk density, particle density and grain size distribution, saturated hydraulic conductivity, the relation of moisture content to soil tension, and Atterberg limits. 


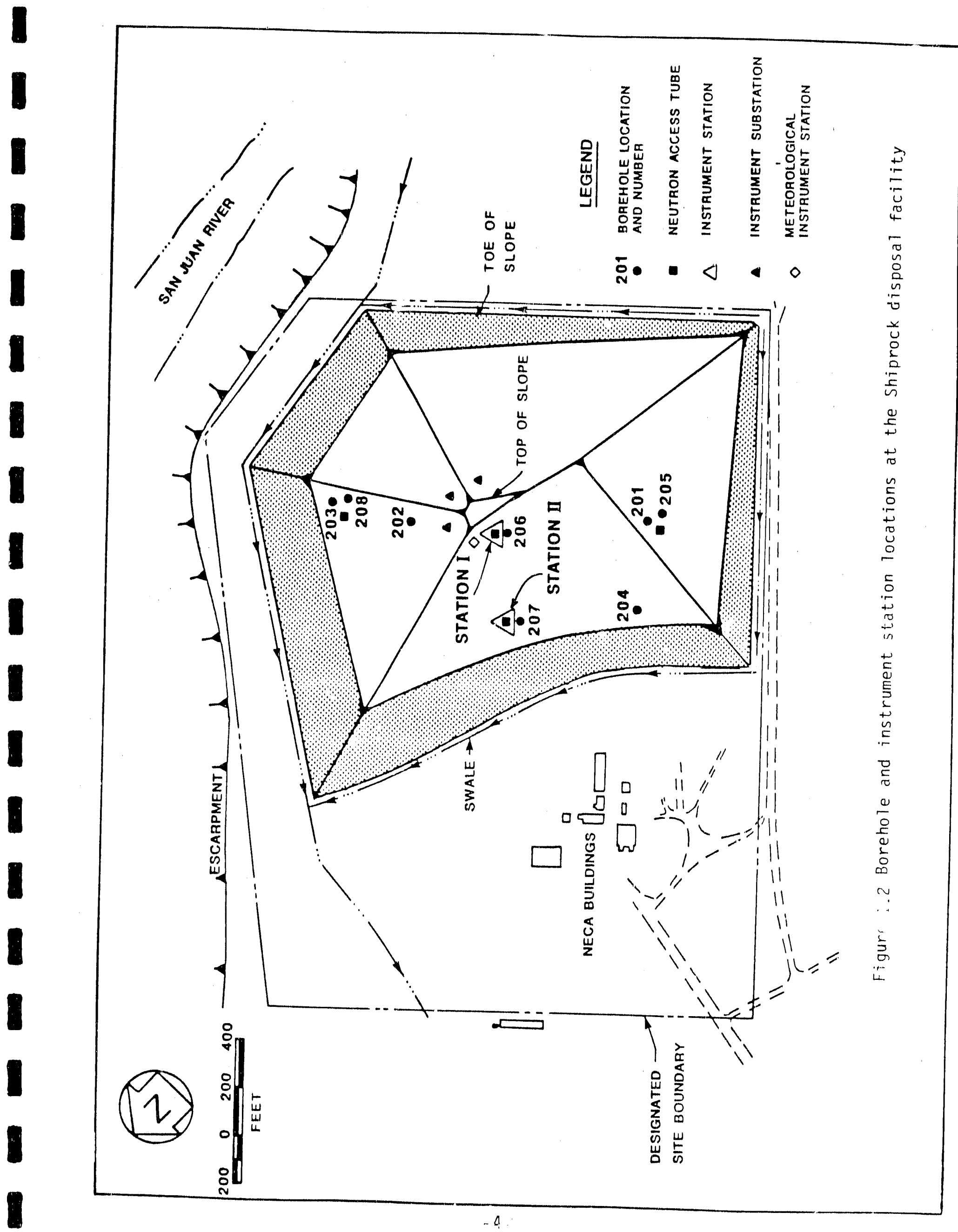


The filter layer and radon barrier at the Shiprock disposal facility were instrumented for continuous monitoring of soil moisture and soil tension. Tensiometers and gypsum blocks were installed at three substations and two instrument stations on the disposal facility. These instruments were installed in the filter layer and to depths of 48 inches into the radon barrier. Tensiometers were equipped with transducers at Station I and data were recorded electronically with a data logger. Elsewhere, the tensiometers were fitted with Bourdon gages and soil tensions were recorded manualiy. Instrumentation at Station I is shown on Figure 1.3. An evaporation pan was placed beneath the riprap for several days to directly measure evaporation through the riprap. Microlysimetry was also conducted in the filter layer to measure evaporation from the filter sand.

Four neutron-probe access tubes were installed through the cover. Bentonite seals were used to prevent flooding of these boreholes, and radon barrier samples were collected along the entire profile of each hole for moisture content analyses to verify the neutron probe logging results. Neutron probe calibration was done by remolding radon barrier materials to design specifications in a steel cylinder and calibrating the probe to a wide range of moisture contents. Neutron logging has been conducted by Dan Stevens \& Associates on a bimonthly basis to assess the movement of any wetting fronts within the radon barrier.

Meteorological information was recorded by the data iogger. A tipping-bucket raingauge, anemometer, four thermal probes, two heat flux plates, two psychrometers, and a net-radiometer were used to measure precipitation, wind, temperature, heat flux, relative humidity, and solar radiation, respectively. 


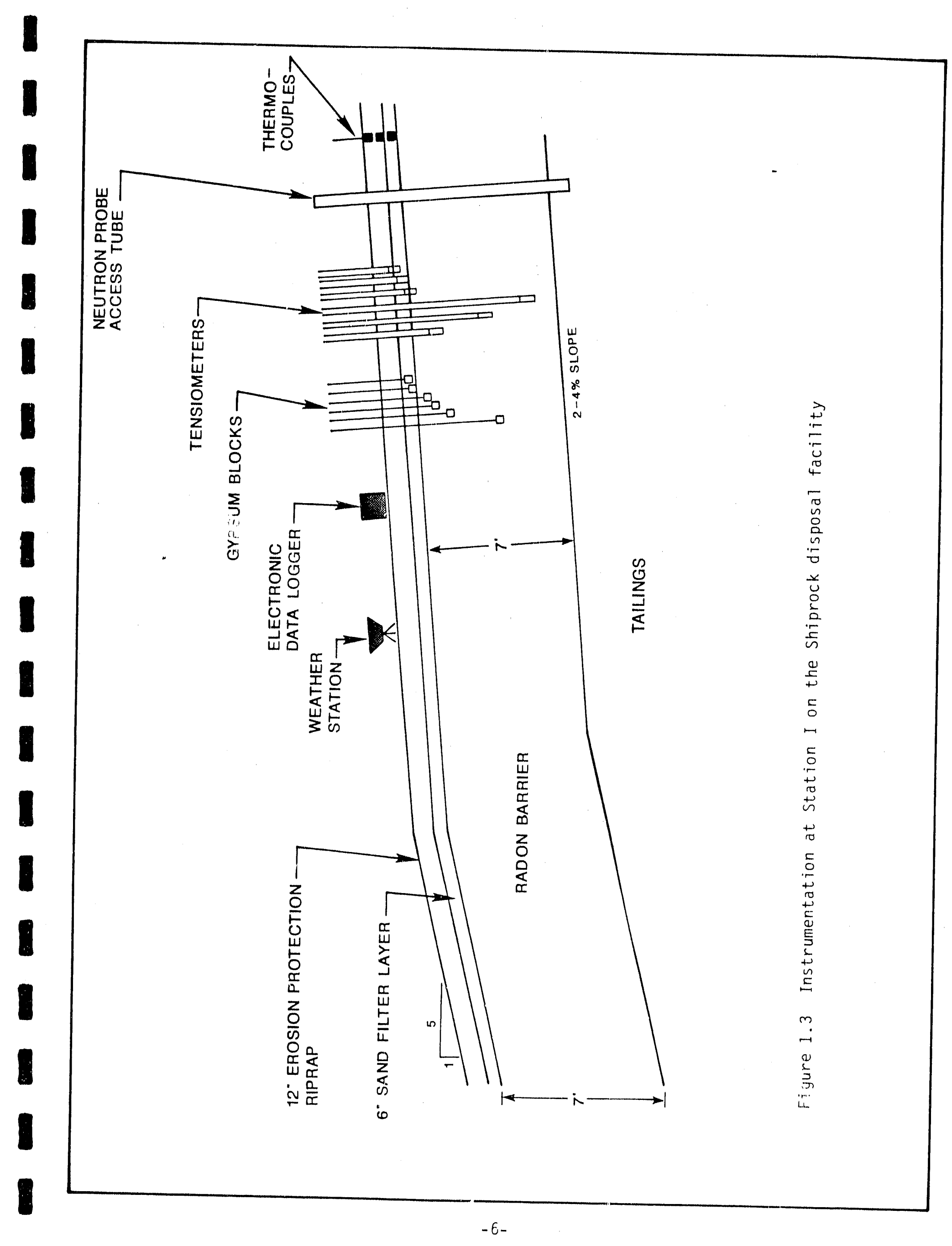


Profiles of percent saturation versus depth, from añalyzing core samples from a11 three study sites, are presented in Figures 2.1 and 2.2. The Shiprock and Clive samples were collected in April 1988, and the Burrell samples were collected in July 1988. Soil characteristics data for the three radon barriers are presented in Attachment. A. Samples from the Shiprock and Clive radon barriers averaged 84 and 82 percent saturation, respectively, while the Burrell radon barrier averaged 86 percent. Moisture profiles of the core data show that the percent saturation is relatively constant with depth. Samples with low percent saturation at Shiprock and Clive (Figure 2.1) are of tailings at depths below the radon barrier. Observed moisture contents in the radon barrier at Shiprock are slightly less than the percent saturations reported at the time of placement. This may be the result of drying during placement, rather than post-closure drainage of placement moisture from the radon barrier.

Moisture content profiles determined by neutron probe logging at Shiprock are presented in Figure 2.3. Periodic neutron logging produces time-related data that allow recognition of wetting or drying fronts. The neutron probe moisture content profiles are consistent with the laboratory analyses of cores and show that moisture contents are relatively constant with depth. Vertically uniform moisture contents in the homogeneous radon barrier suggest that the hydraulic gradient is unity. Within the upper foot of the radon barrier, changes in apparent moisture content between June 1988 and August-September 1988 are inferred to relate to hydration of a bentonite seal placed around the upper annulus of the probe-access tube on July 16. Presently the neutron probe logging provides only a relative measure of moisture content. However, the probe will be recalibrated, using measurements of moisture content in soil cores, to reflect actual moisture contents within the radon barrier.

Soil tension was measured with tensiometers at two instrument stations and three substations on the Shiprock disposal facility. Soil tension in the filter layer, and from three inches to 48 inches into the radon barrier, are shown on Figures 2.4-2.7. Precipitation events greater than 0.1 inch measured at the weather station on the disposal facility are presented on Figures 2.5-2.7. Soil tension in the filter layer is relatively high except during a short period of saturation following a large precipitation event. The tensiometer data show that water in the filter layer drains or evaporates within a few days after a major precipitation event and soil tension then begins to increase until the next precipitation event.

At a depth of three inches into the radon barier, soil tensions responded to wetting of the filter layer after a major precipitation event on June 28,1988 . This was a very intense storm, with more than one inch of rain in 30 minutes. A tensiometer in the radon barrier at a depth of three inches (Figure 2.5) at Station II shows a gradual reduction of soil tension following the precipitation event. However, the immediate decrease in soil tension at a depth of three inches in the tensiometer at Station I probably reflects water leaking down the side of the tensiometer borehole rather than an immediate change in soil tension propogating through the radon barrier.

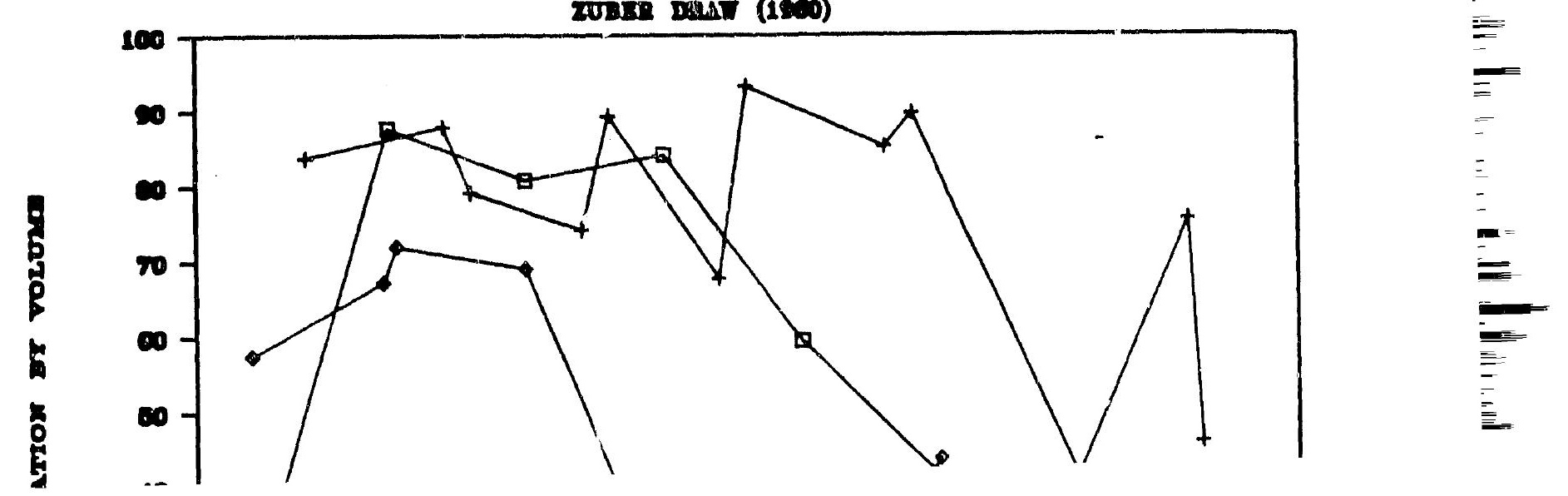



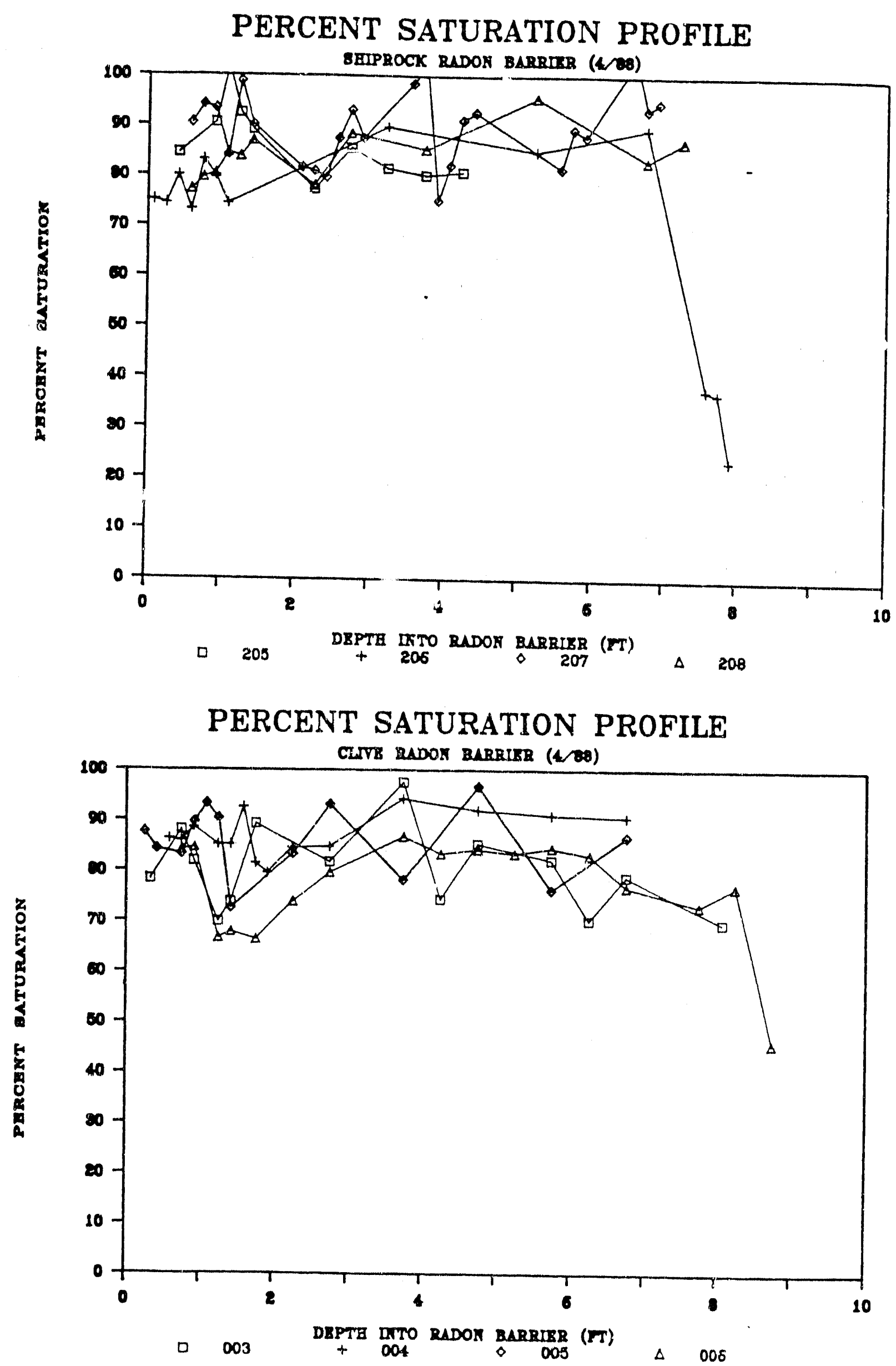

Figure 2.1 Profiles of percent saturation versus depth from core samples at
Shiprock and Clive 


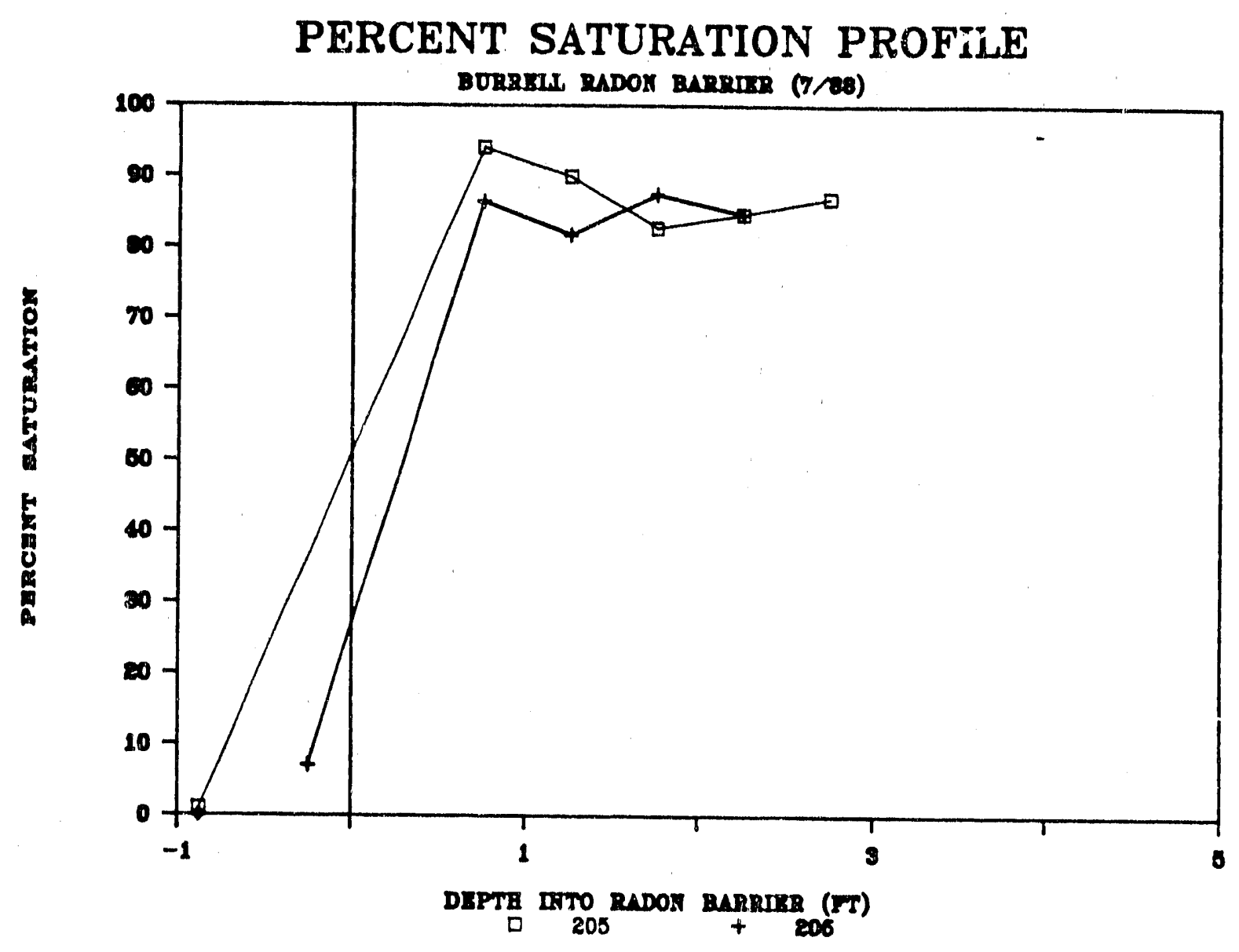

Figure 2.2 Profiles of percent saturation versus depth from core samples at Burrel? 


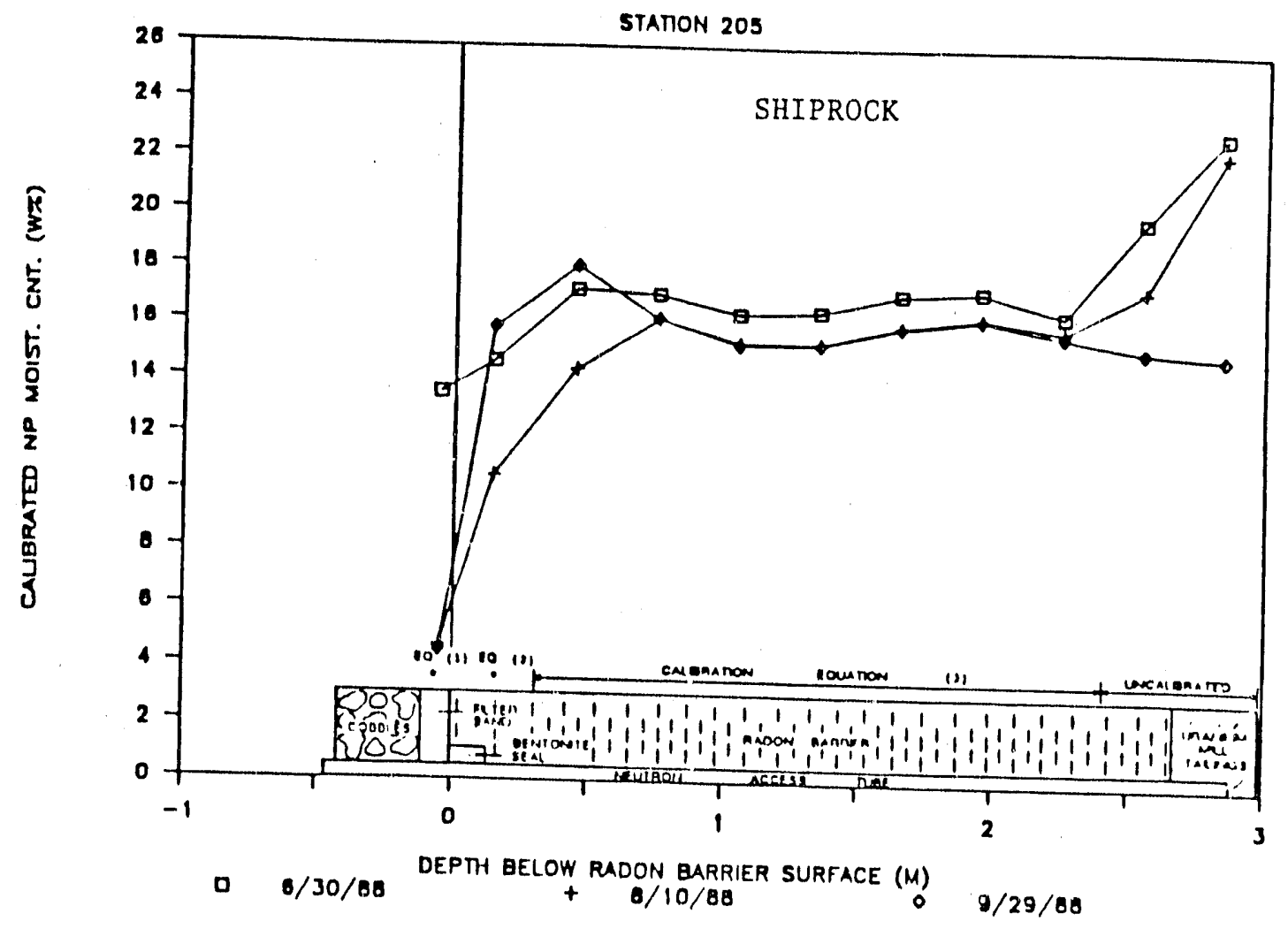

Figure 2.3. Moisture content profiles for Station 205 on June 30, August 10 , and September 29,1988 , determined by
neutron probe logging 


\section{RADON BARRIER SOIL TENSION}

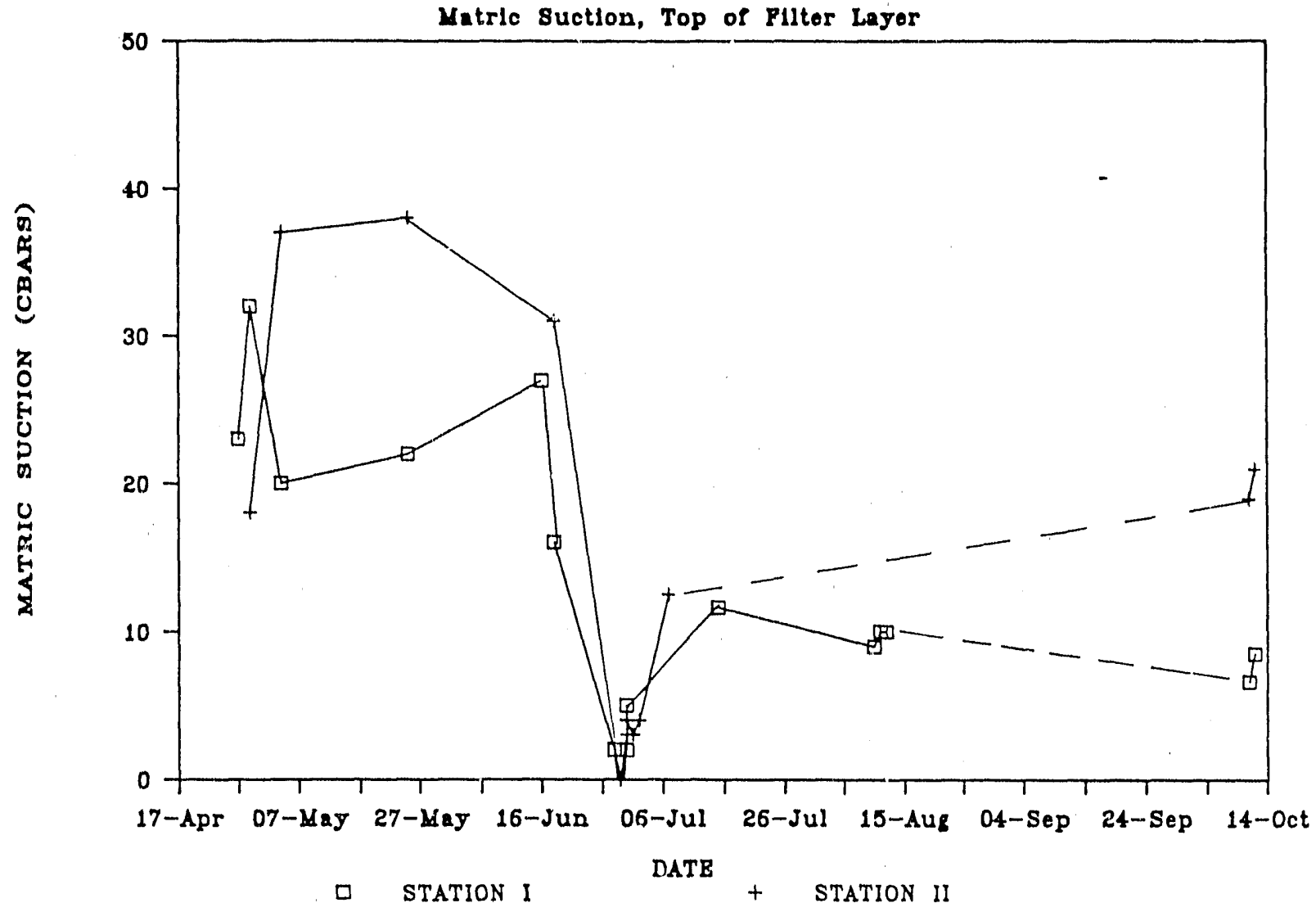

RADON BARRIER SOIL TENSION

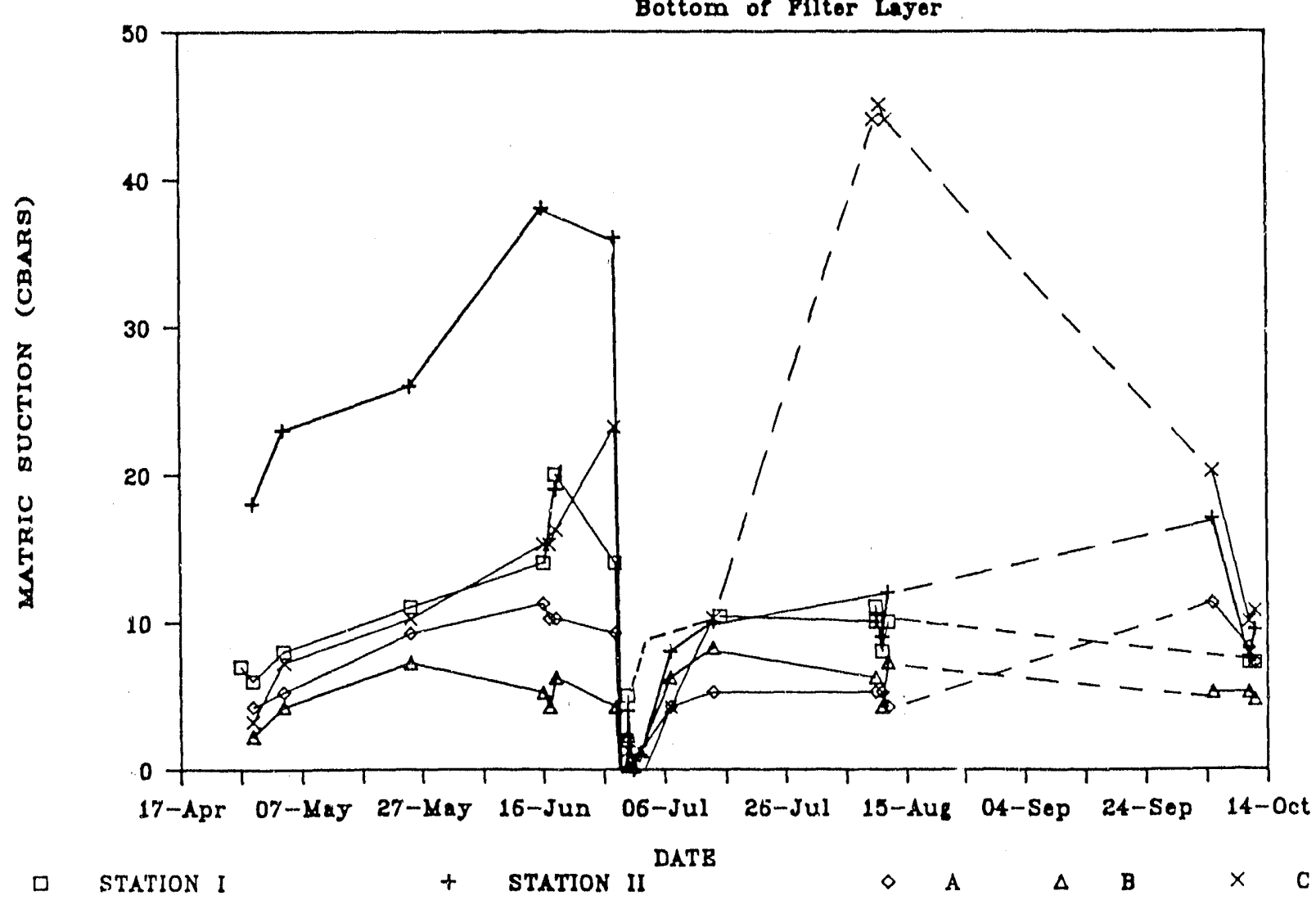

Figure 2.4 Soil tension measured at the top and bottom of the filter layer at Shiprock 


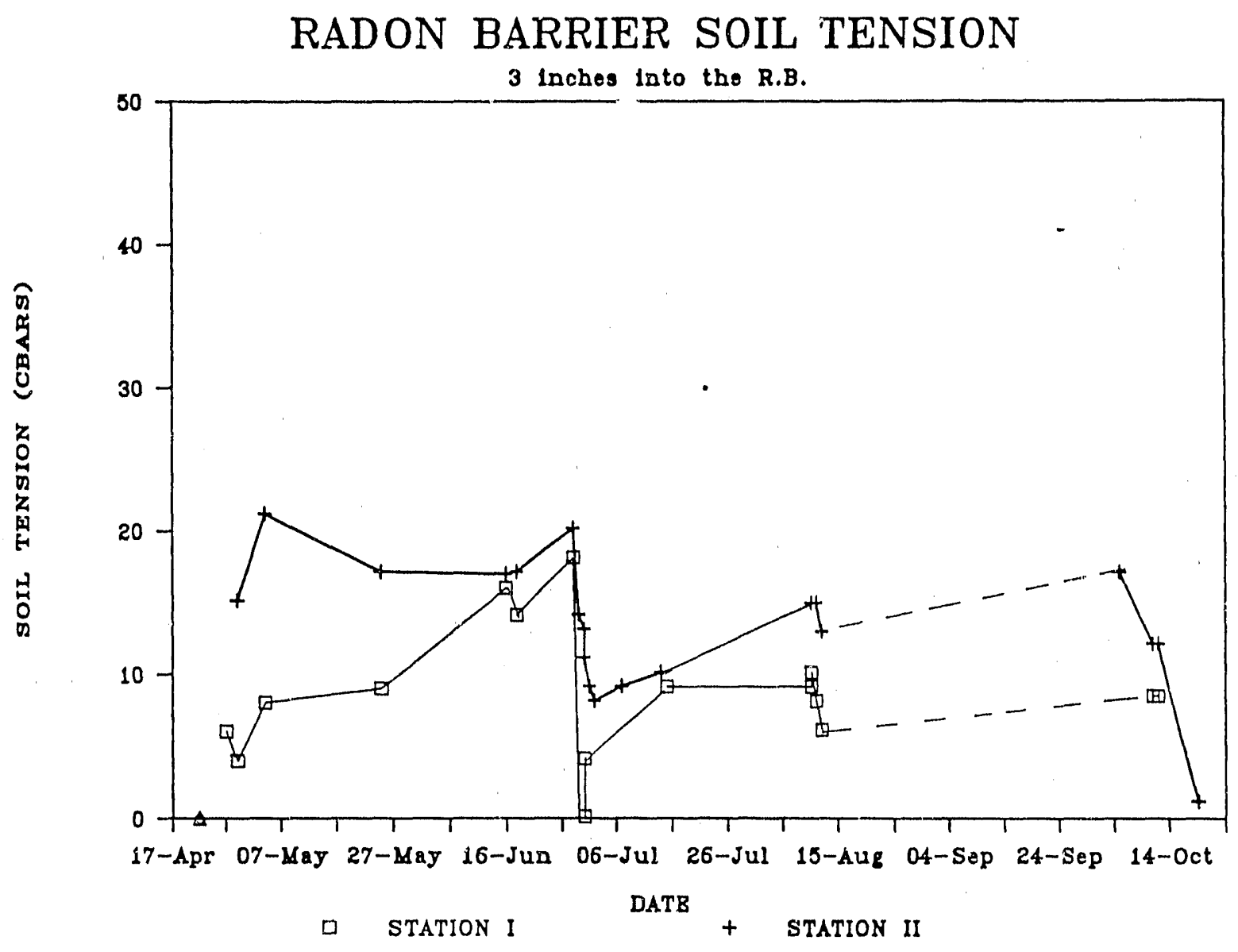

RADON BARRIER SOIL TENSION

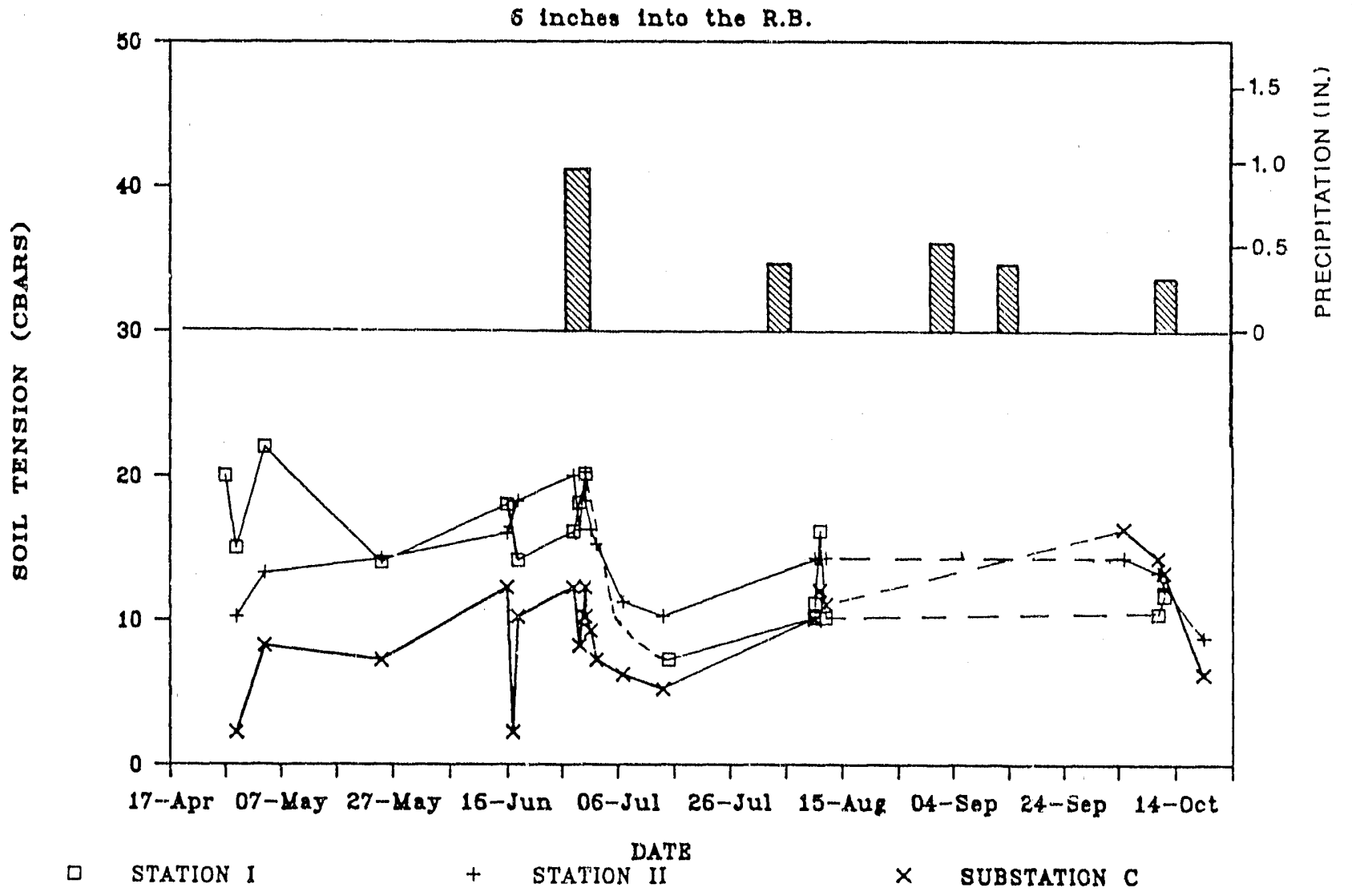

Figure 2.5 Soil tension measured at depths of 3 and 6 inches into the radon barrier at Shiprock 

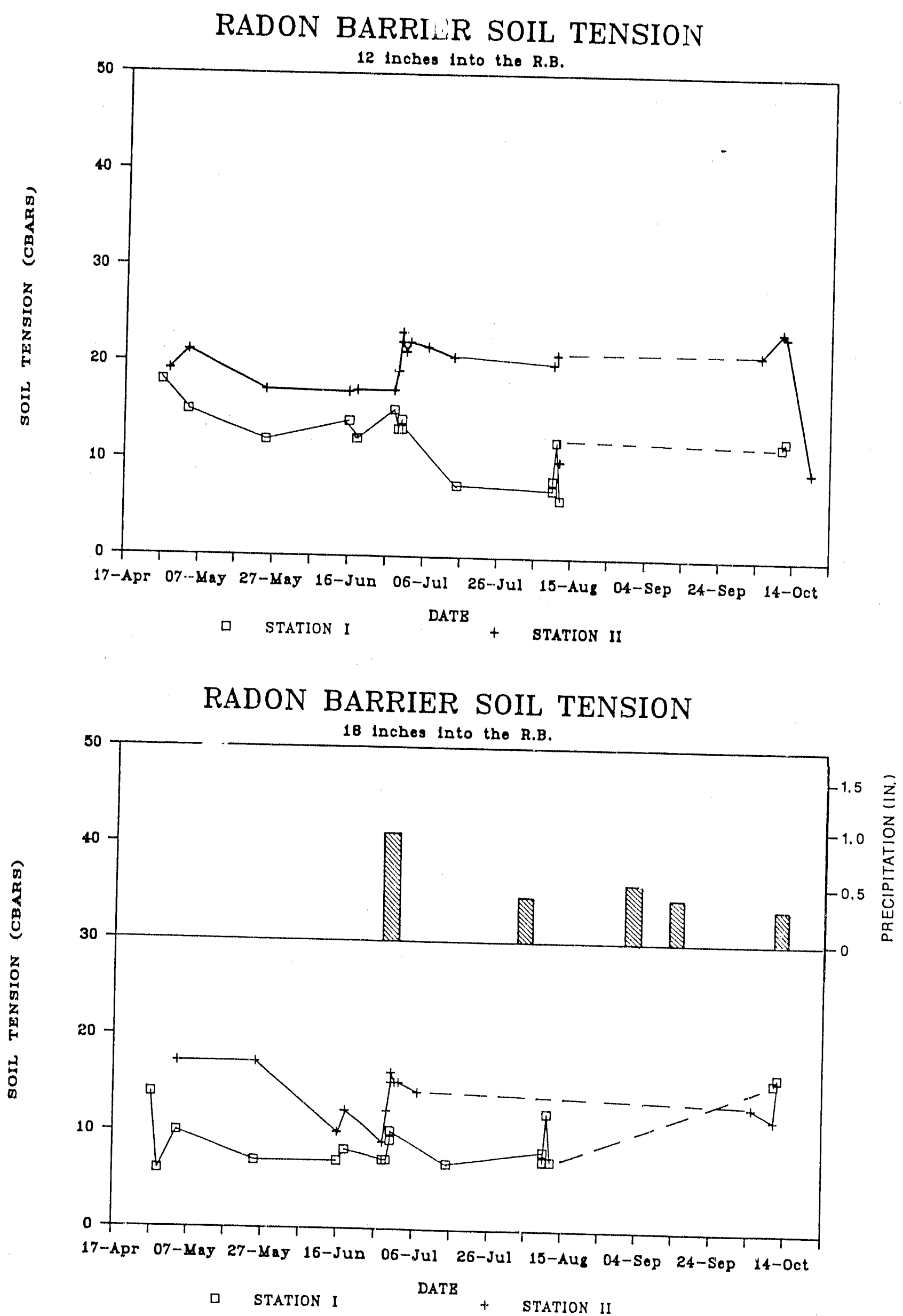

Figure 2.6 soil tension measured at depths of 12 and 18 inches into the radon barrier at Shiprock 

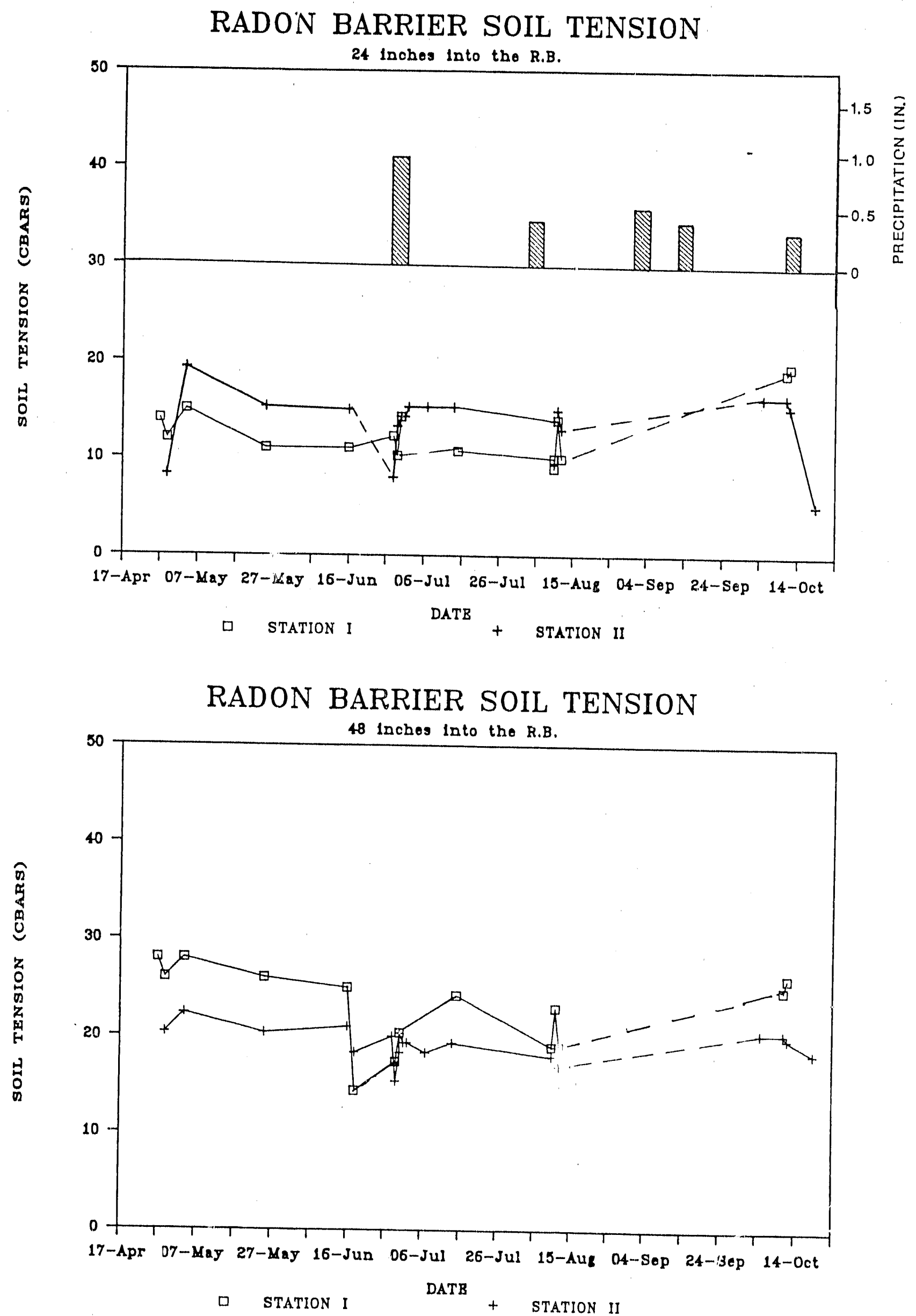

Figure 2.7 Soll tension measured at depths of 24 and 48 inches into the filter layer at Shiprock 
Tensiometers placed six inches into the radon barrier also responded to this precipitation event, as shown by gradually decreasing soil tensions during the following three weeks (Figure 2.5). At a depth of 12 inches (Figure 2.6) soil tension declined in a tensiometer at Station I, but no response is indicated in the tensiometer at station II. Tensiometers placed 18 inches or deeper within the radon barrier (Figures 2.6 and 2.7$)$ showed no response to the precipitation event.

Because fluctuations in soil tension at six inches, or possibly to 12 inches, do not propagate downward, evaporation through rock layers is concluded to be an effective mechanism for removal of cover moisture from typical UMTRA Project covers in semiarid climates. The rate and depth of drying following a precipitation event indicate that evaporation losses are significant. To estimate potential evaporation, a screened evaporation pan was installed below the erosion protection riprap at the level of the filter layer. During a two-day period, a cumulative loss of 0.16 inch of water was observed. This measured evaporation rate is an order of magnitude larger than that attributable to molecular diffusion of water vapor through the riprap. Hence, advection of moisture through the large pore spaces by circulating air must contribute markedly to the higher evaporation rate. Factors that affect the advection of moisture, such as wind speed, riprap thickness and size, air temperature, and rock temperature, may significantly affect evaporation.

Laboratory determinations of percent saturation versus soil tension in the Shiprock radon barrier are shown on Figure 2.8. The two groups of curves, which diverge with respect to soil tension by approximately one order of magnitude for the same percent saturation, correspond to two different methods of sample collectiol. The lower group of curves, which was generated from tests performed on urass-ring samples, indicates that soil tensions should range from one to two bars at 84 percent saturation (the average saturation measured from core samples of the radon barrier at Shiprock). The upper group of two curves $(205 \& 206)$, which was generated from tests on CME samples, indicates that tensions of 11 to 16 bars should occur at approximately 84 percent saturation. The lower group of curves is not typical of fine-grained materials, suggesting that these samples are disturbed.

The relations of hydraulic conductivity to percent saturation for the Shiprock and Clive radon barriers (Figure 2.9) were developed using an algorithm that calculates "relative" hydraulic conductivity from the laboratory-measured relation of percent saturation to soil tension (Van Genuchten, 1985; Mualem, 1976). The unsaturated hydraulic conductivity is then calculated by multiplying the relative hydraulic conductivity by the saturated hydraulic conductivity. On each figure, the intersect of the average percent saturation for that site with the average hydraulic conductivity curve indicates the gperational unsaturated conducfivity. This is on the order of $1 \times 10^{-9} \mathrm{~cm} / \mathrm{s}$ for shiprock and $1 \times 10^{-13} \mathrm{~cm} / \mathrm{s}$ for Clive. 


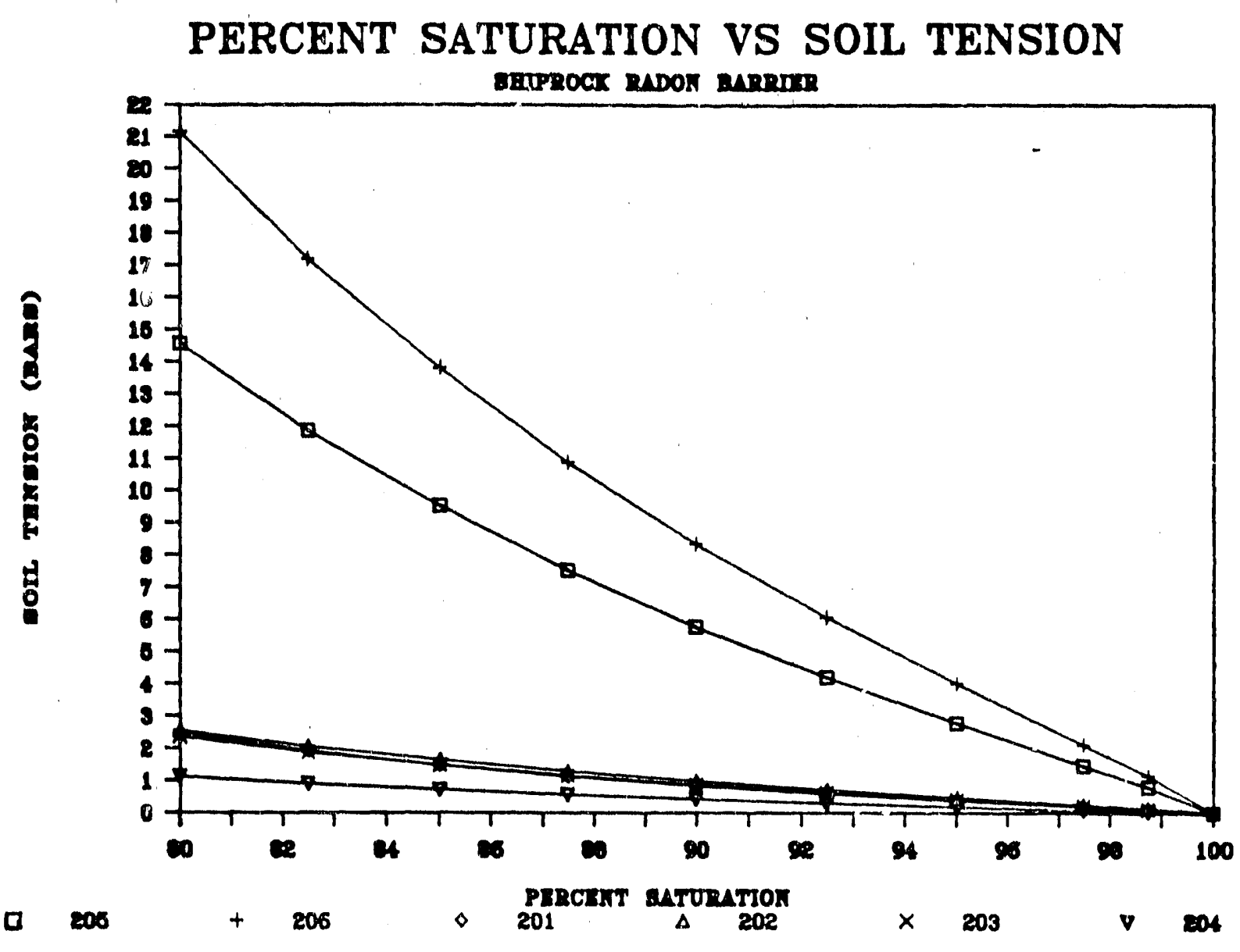

Figure 2.8 Relation of percent saturation to soil tension in the radon barrier at the Shiprock disposal facility 

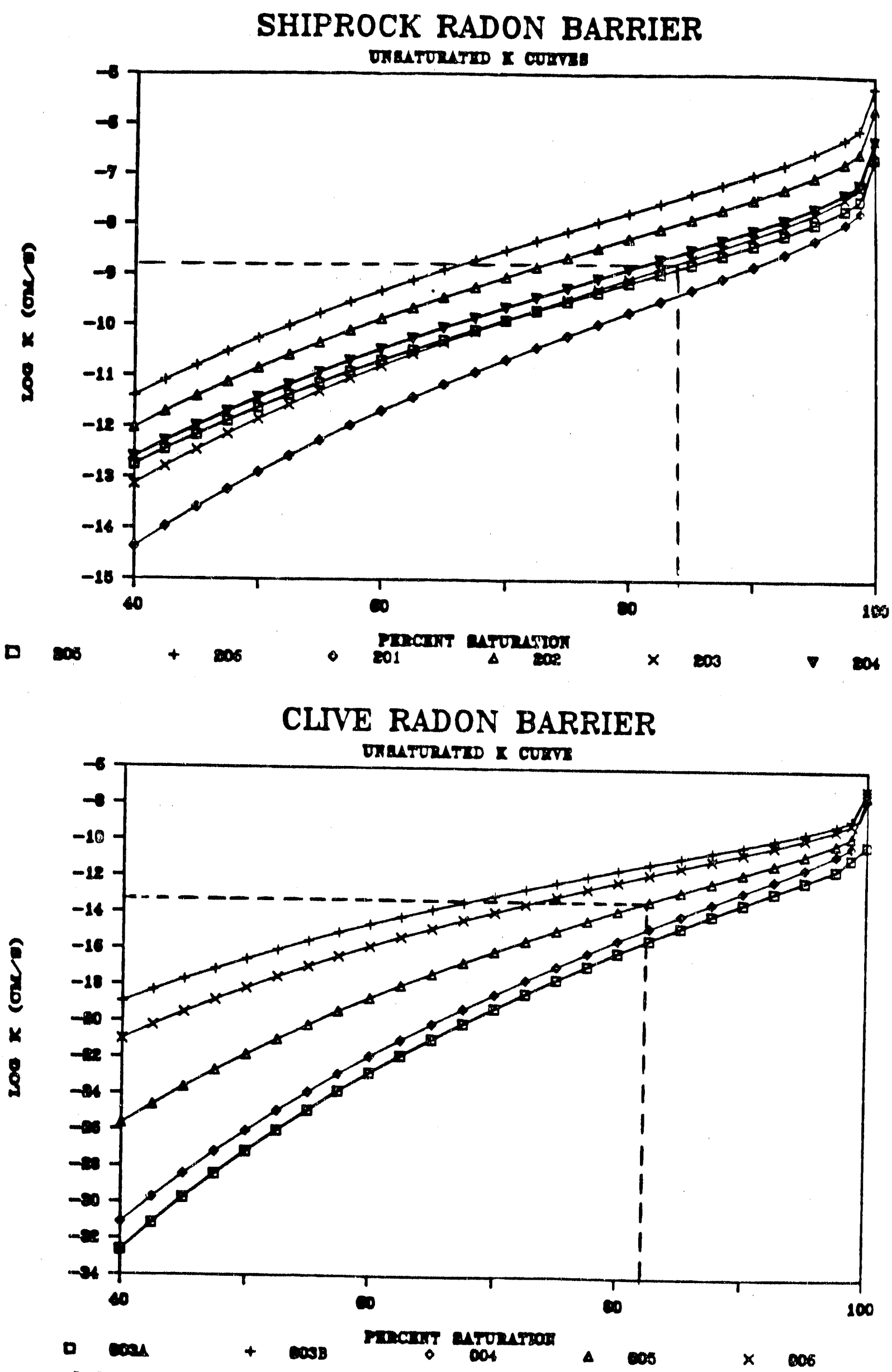

Figure 2.9 Relation of hydraulic conductivity to percent saturation for the Shiprock
and Clive radon barriers 
The unsaturated hydraulic conductivity curves in Figure 2.9 that were generated by this method are sensitive to the saturated hydraulic conductivity but are relatively insensitive to the variations introduced by sampling technique, which produced two divergent groups of curves in Figure 2.8. Inspection of the unsaturated hydraulic conductivity curves for Shiprock shows that the curves generated by the Mualem method for the two sample sets collected by a CME sampler (samples 205 and 206) fall within the range of curves generated from the four sample sets collected using brass rings.

\section{Conclusions from the Shiprock Field Program}

Results of the Shiprock field program indicate that soil tension in the upper portion of the radon barrier responds to meteorological conditions. Temporal fluctuations in soil tension diminish with depth in the radon barrier, and none are observed below 12 inches. So 11 tensions change much more rapidly than percent saturation. The propagation of the average percent saturation will be very slow because the movement of water through the radon barrier is restricted by the low unsaturated hydraulic conductivity. Generally:

1. Observed percent saturations in the radon barrier at Shiprock are slightly less than the placement percent saturation. This may be the result of drying during placement, when the materials were exposed to air. There is too much uncertainty in the placement data to attribute the reduction in percent saturation to post-closure drainage of moisture from the radon barrier.

2. Tensiometer data from Shiprock suggest that soil tension in the upper 12 inches of the radon barrier is influenced by changes in saturation in the filter layer. The filter layer is only occasionally saturated after large precipitation events. The soil tension in the upper radon barrier decreases after large precipitation events but soon increases as evaporation takes place. Moisture profiles from neutron probe data suggest moisture contents are relatively constant with time and depth below the upper portion of the radon barrier. In no case was a front of saturation observed to be propagating downward through the radon barrier.

3. The low unsaturated hydraulic conductivity of the radon barrier and the relatively uniform moisture distribution suggest that changes in moisture content will not propagate below the top 12 inches. Based on the first six months of field data, moisture that has infiltrated the radon barrier is held within the top 12 inches of the radon barrier until it is evaporated.

4. The uniform percent saturation in the radon barrier implies a hydraulic gradient of unity. Seepage rates are then equal to the unsaturated hydraulic conductivity of the radon barrier at the existing moisture content. This yields an unsaturated flux through the radon barrier at Shiprock of approximately $1 \times 10^{-9}$ $\mathrm{cm} / \mathrm{s}$. 


\subsection{MOISTURE DATA FROM LONG-ESTABLISHED SMALL DAMS}

A literature review for data on the long-term movement of moisture and percent saturation of covers constructed of materials with low unsaturated hydraulic conductivities produced information on four small, earth-fill flood-control dams in New Mexico. The dams range from 15 to 27 years old. While they were not rock-covered at the time they were studied by the U.S. Soil Conservation Service (SCS), their moisture characteristics measured during that study are informative for the UMTRA Project. The dams are on small drainage basins, and they impound water only during occasional heavy runoff.

The SCS provided data on percent saturation versus depth that had been collected as a result of concern with surface cracking. Profiles of percent saturation for four earth-fill dams are shown on Figure 3.1. In the dams, the maximum percent saturation consistently averaged about 80-90 percent. The maximum percent saturations for each of the dams tend to occur at middle depths in the profiles. The relatively low percent saturations found at depth in several of the profiles are from the more permeable foundation strata below the base of the dams. Where low percent saturations are shown in upper parts of the profiles, this is inferred to result from evaporation; surficial desiccation cracks in the dams appear to have facilitated evaporation to relatively great depths. The SCS's aim in studying the dams was to determine the cause of cracking. After ascertaining that the dams were drying near the surface, the SCS remedied the problem by adding a rock mulch to their upper surfaces.

Because of differences between the dams at the time of sampling and typical UMTRA Project cover designs, specifically, that the dams had no rock mulch on their top surfaces, the comparison of moisture characteristics is limited to the observation that these semiarid-zone dams are unsaturated. This is an example of how the low unsaturated hydraulic conductivity of the cover materials can restrict the downward redistribution of moisture and prevent vertical seepage of infiltration, but allow significant evaporation so that low percent saturations may occur in the upper portion of the cover materials. 

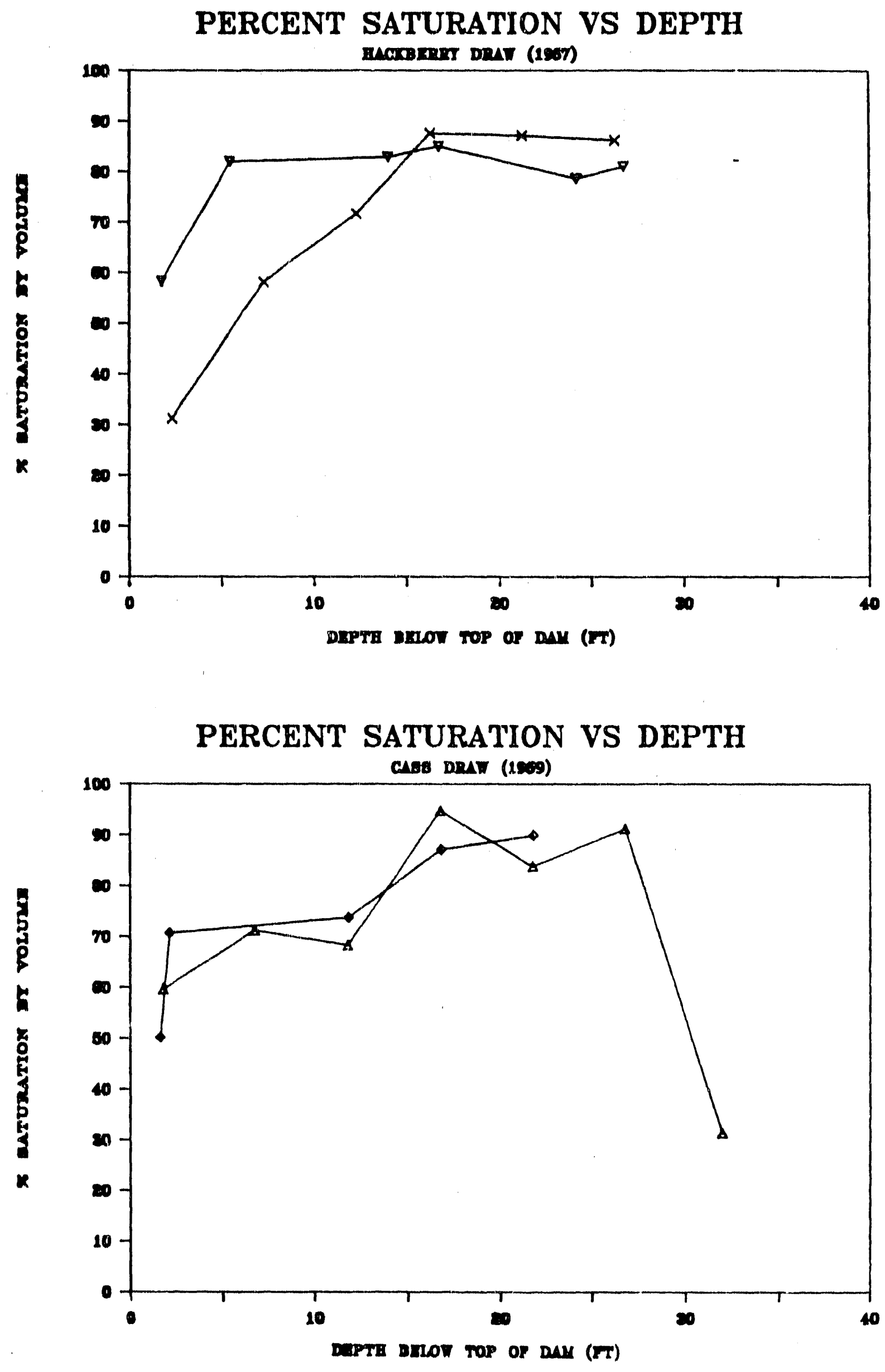

Figure 3.1 Profiles of percent saturation for four earth-fill dams $-20-$ 

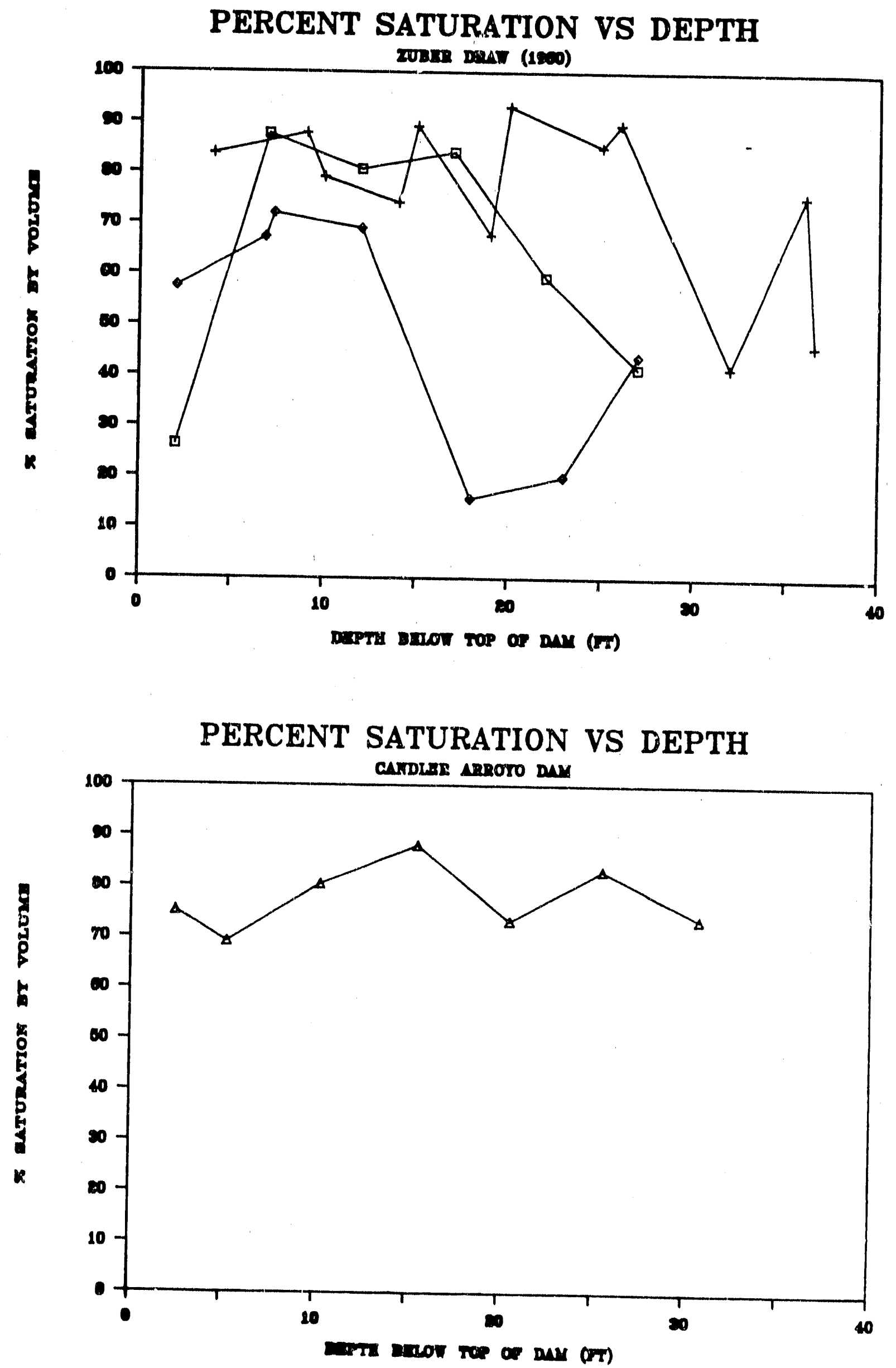
Figure 3.1 (continued) Profiles of percent saturation for four
earth-fill dams 


\subsection{EXPECTED PERFORMANCE OF TYPICAL COVERS AT SEMIARID SITES}

Presently, typical UMTRA Project covers have been completed at the Shiprock, Clive, and Burrell sites, and are planned or under construction at Ambrosia Lake (NM), Green River (UT), Lakeview (OR), Mexican Hat (UT), Slick Rock (CO), and Tuba City (AZ). With the exceptions of Burrell and Lakeview, ail of these sites are in semiarid regions and have comparable precipitation and potential evaporation. A summary of site climatological characterization data for the UMTRA Project sites is presented in Table 4.1.

The combination of the low unsaturated hydraulic conductivity of the radon barrier and evaporation through the filter layer and erosion protection riprap is an effective design that prevents the radon barrier from becoming saturated and limits infiltration into the tailings. Therefore, it is qualitatively predictable that typica? UMTRA Project covers will function similarly in similar climatic environments. Radon barriers in typical covers at sites having climates similar to Shiprock and clive should operate in an unsaturated state.

With respect to sites and climates, radon barriers in typical UMTRA Project covers would operate in an unsaturated state at the Ambrosia Lake, Green River, Mexican Hat, Slick Rock, and Tuba City UMTRA Project sites. The remedial action is still in the design phase or is not completed at these sites. In general, these sites are in high altitude, semiarid environments that range in elevation from 4,070 to 6,980 feet. The average annual precipitation is less than 10 inches and is derived mainl $j$ from short, intense storms. Snowfall comprises only a small percentage of annual precipitation. The average annual pan evaporation exceeds precipitation by aimost an order of magnitude and the average annual temperature is high.

The design of the typical UMTRA Project covers for these sites incorporates cover geometry, layers, and material characteristics that are similar to those of the Shiprock disposal facility. Commonly, the design attempts to achieve a saturated nydraulic conductivity of $1 \times 10^{-1} \mathrm{~cm} / \mathrm{s}$ in the radon barrier using fine-grained soils compacted wet of optimum. Other components of the cover design have been evaluated to optimize the operation of the cover system towards unsaturated conditions and restrict infiltration through the radon barrier. For instance, the hydraulis. conductivity of the filter layer can be increased, the slope of the filter layer increased, and the length of flnw paths through the filter layer to the edge of the disposal facility can be shortened so that the filter layer can shed water as quickly as possible. These design modifications would decrease the amount of time that the filter layer is saturated, thereby reducing the availability of water to infiltrate the radon barrier. In some cases the filter layer can be removed without creating an erosion 


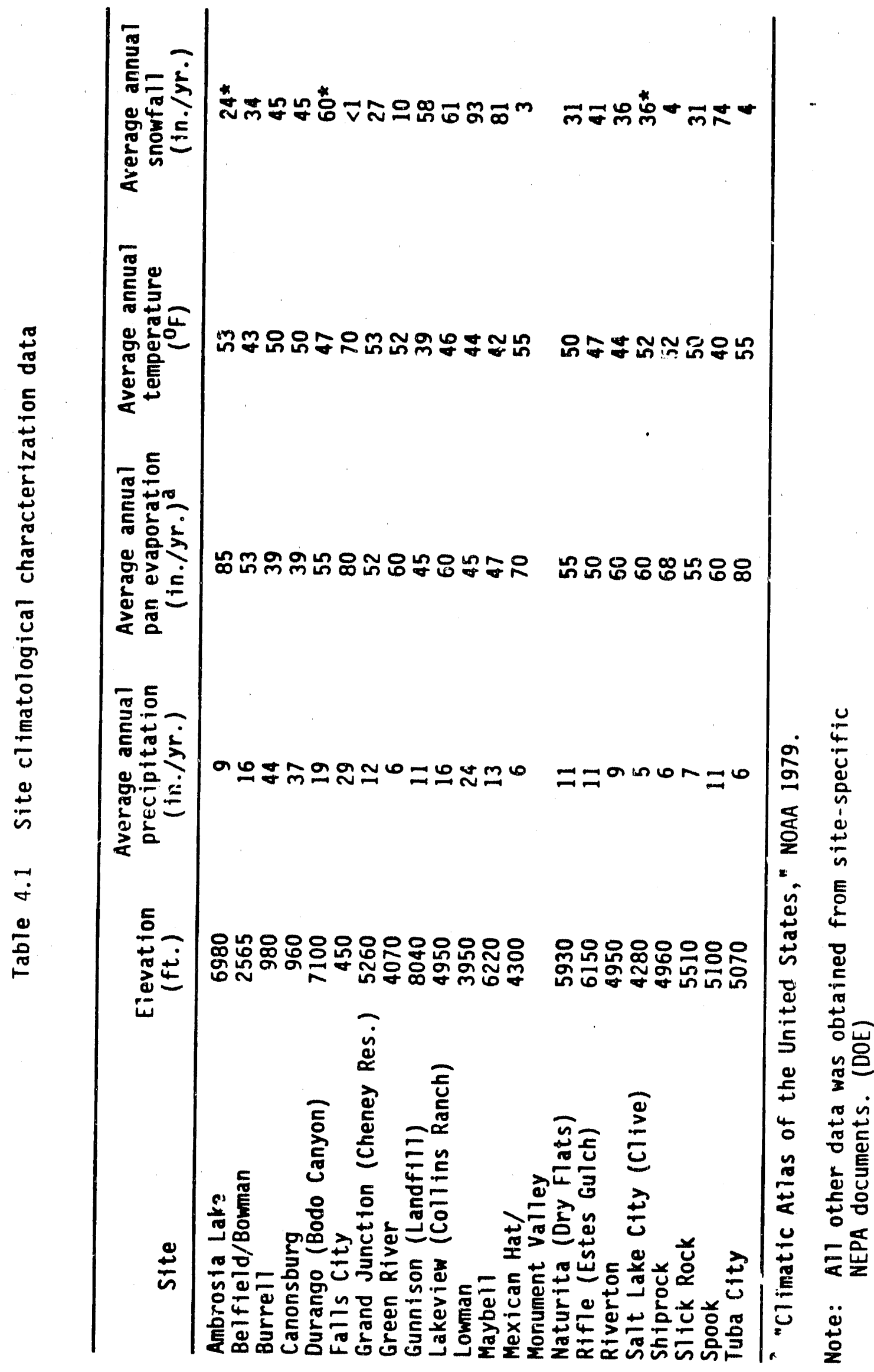


potential at the interface with the radon barrier. This could further decrease the length of time to shed water off the disposal facility, because flow would occur through large pores in the erosion protection riprap. It may be possible to grade the size of the erosion protection riprap or filter sand to optimize evaporation from the filter sand and racion barrier. These optimization concepts will be incorporated, where beneficial, into the design of typical UMTRA Project covers.

Because of concern whether repeated freeze-thaw cycles will increase the hydraulic conductivity of unsaturated radon barrier material, designs of typical UMTRA project covers will incorporate at least one foot of radon barrier material below the maximum frost depth. This will assure that even if the upper portion of the radon barrier is disrupted by expansion of water in the unsaturated interstices during freezing, there will still be a sufficient thickness of operational radon barrier to restrict infiltration to the tailings.

A typical UMTRA Project cover on the sideslopes of a disposal cell may be combined with a nearly flat, vegetated upper surface of a cover at UMTRA Project sites with higher precipitation. This design has been proposed for the Cheney Reservoir disposal cell for the tailings at Grand Juncticn, Colorado. The rock-covered sideslope is expected to remain unsaturated in an environment with as much as 12 inches of annual precipitation. Site and climate-specific modeling of the effectiveness of the vegetation in removing moisture from the top surface of the piles indicates that water rarely percolates through the vegetated soil layer to reach the filter layer. On the sideslopes, therefore, the filter layer will receive water from only precipitation on the sloping rock surface, and it will receive negligible drainage water from the extensive vegetated upper surface of the disposal cell. Water in the high hydraulic conductivity filter layer will drain rapidly down the steep sideslopes. This greatly reduces the time when water in the filter layer is available for infiltration through the radon barrier. When this rapid drainage effect is considered along with the substantial evaporative removal of water that has been demonstrated in the study of the Shiprock cover, it is probable that the radon barrier beneath the rock-covered sideslopes will operate under a low unsaturated hydraulic conductivity and that infiltration through the radon barrier in that portion of the disposal cell will be minimal.

The question of whether typical UMTRA Project covers may operate under unsaturated conditions at sites with substantially higher precipitation than at the Shiprock disposal site has not been fully resolved. Analysis of percent saturations of core samples of the radon barrier from the Burrell disposal facility suggests that the radon barrier has not become saturated since placement. Furthermore, there is no direct evidence that typical UMTRA Project covers in areas of higher precipitation will be saturated. 


\section{REFERENCES}

Maulem, Y., 1976. "A new model for predicting the hydraulic conductivity of unsaturated porous media," in Water Resources Res., 12(3), pp $513-522$.

Van Genuchten, M. T., 1985. "On describing and predicting the hydraulic properties of unsaturated soils," in Annals Geophysicae, 3(5), pp 615-628. 


\section{ATTACHMENT A \\ SOIL CHARACTERISTICS DATA FOR THE \\ RADON BARRIERS AT \\ SHIPROCK, CLIVE, AND BURRELL}


COVER MOISTURE STUDY GE(TECHNICAL DATA (10/31/8B)

SHIPROCK RADON BARRIER DATA:

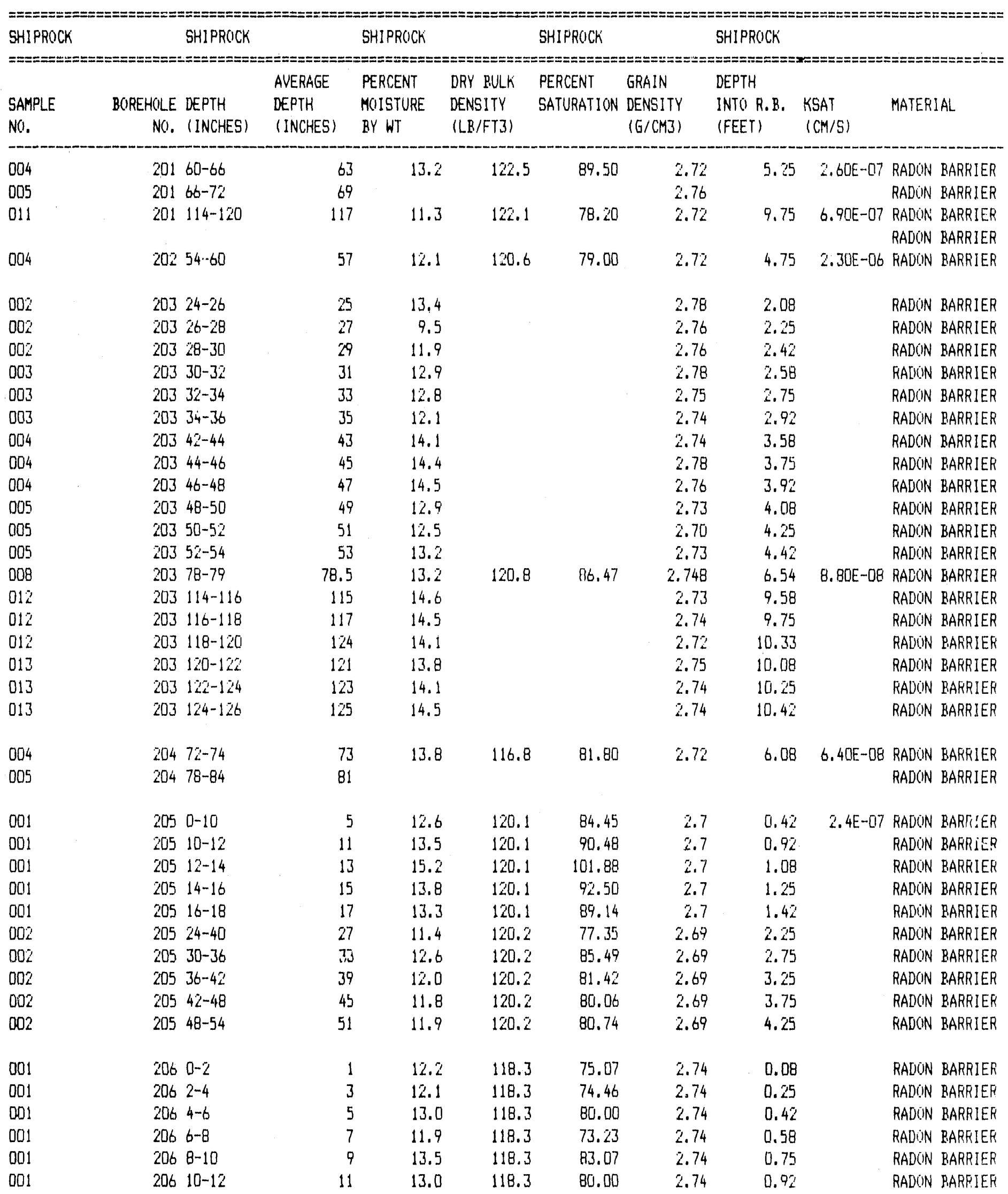


COVER MOISTURE STUDY GE(ITECHNICAL DATA $(10 / 31 / 88)$

SHIPROCK TAILINGS DATA:

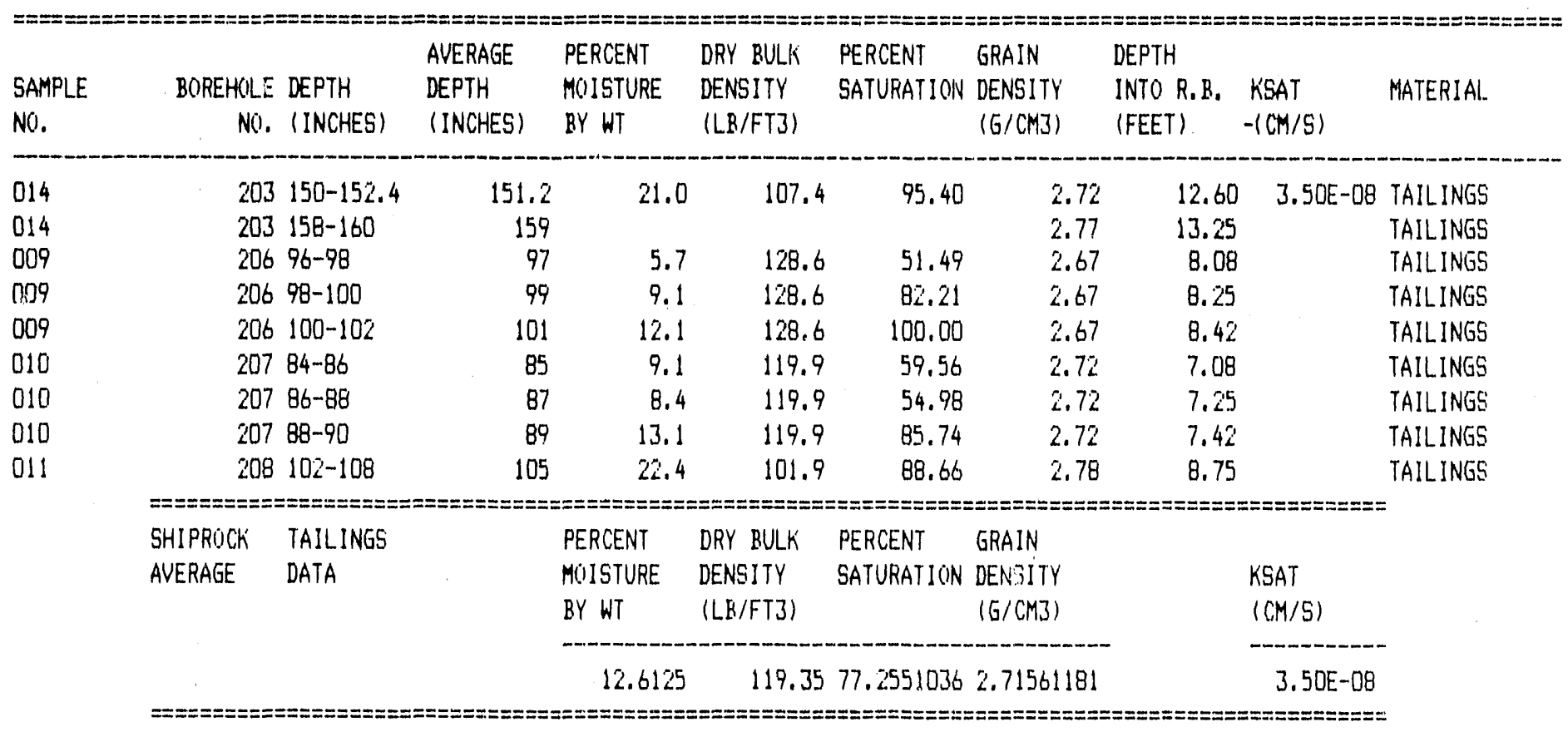




\begin{tabular}{|c|c|c|c|c|c|c|c|c|c|}
\hline 001 & $206 \quad 12-14$ & 13 & 12.1 & 118.3 & 74.46 & 2.74 & 1.08 & & RADON BARRIED \\
\hline $00 \%$ & $206 \quad 36-42$ & 39 & 13.9 & 117.2 & 89.64 & 2.65 & 3.25 & & RADON BARRIER \\
\hline 005 & $206 \quad 60-66$ & 63 & 11.6 & 123.1 & 84.96 & 2.7 & 5.25 & & RADON BARRIER \\
\hline 007 & $20678-84$ & 81 & 11.6 & 124.8 & 89.49 & 2.7 & 6.75 & & RADON BARRIER \\
\hline 008 & $20690-92$ & 91 & 10.5 & 96.2 & 37.73 & 2.7 & 7.58 & & RADCN BARKIER \\
\hline 008 & $20692-94$ & 93 & 10.3 & 96.2 & 37.01 & 2.7 & $7.75-$ & & RALION BARRIER \\
\hline 008 & $20694-96$ & 95 & 6.6 & 96.2 & 23.72 & 2.7 & 7.92 & & RADCN BARRIER \\
\hline 003 & $206 \quad 42-48$ & & & & & 2.74 & & $6.1 E-06$ & RADON BARRIER \\
\hline 001 & $2076-8$ & 7 & 12.2 & 122.8 & 90.36 & 2.68 & 0.58 & & RADON BARRIER \\
\hline 001 & $2078-10$ & 9 & 12.7 & 122.8 & 94.07 & 2.68 & 0.75 & & RADON BARRIER \\
\hline 001 & $20710-12$ & 11 & 12.6 & 122.8 & 93.33 & 2.68 & 0.92 & & RADCIN BARRIER \\
\hline 002 & $207 \quad 12-14$ & 13 & 12.6 & 120.9 & 84.10 & 2.73 & 1.08 & & RADSON BARRIER \\
\hline $00 \%$ & $20714-16$ & 15 & 14.8 & 120.9 & 98.78 & 2.73 & 1.25 & & RADON BARRIER \\
\hline 002 & $20716-18$ & 17 & 13.5 & 120.9 & 90.10 & 2.73 & 1.42 & & RADON BARRIER \\
\hline 003 & $20724-26$ & 25 & 12.4 & 120.1 & 81.62 & 2.72 & 2.08 & & RADCIN BARRIER \\
\hline 003 & $20726-28$ & 27 & 12.3 & 120.1 & 80.96 & 2.72 & 2.25 & & RADON BARRIER \\
\hline 003 & $20728-30$ & 29 & 12.1 & 120.1 & 79.65 & 2.72 & 2.42 & & RADON BARRIER \\
\hline 004 & $20730-32$ & 31 & 12.3 & 123.4 & 87.41 & 2.74 & 2.58 & & RADONN BARRIER \\
\hline 004 & $20732-34$ & 33 & 13.1 & 123.4 & 93.10 & 2.74 & 2.75 & & RADON BARRIER \\
\hline 004 & $20734-36$ & 35 & 12.3 & 123.4 & 87.41 & 2.74 & 2.92 & & RADON BARRIER \\
\hline 005 & $207 \quad 42-44$ & 43 & 14.3 & 122.3 & 98.45 & 2.74 & 3.58 & & RADON BARRIER \\
\hline 005 & $20744-46$ & 45 & 14.4 & 122.3 & 102.58 & 2.74 & 3.75 & & RALON BARRIER \\
\hline 005 & $20 ? 46-48$ & 47 & 10.9 & 122,3 & 75.04 & 2.74 & 3.92 & & RADON BARRIER \\
\hline 006 & $20748-50$ & 49 & 10.8 & 126.0 & 82.07 & 2.75 & 4.08 & & RADON PARRIER \\
\hline 006 & $20750-52$ & 51 & 12.0 & 126.0 & 91.18 & 2.75 & 4.25 & & RADON BARRIEK \\
\hline 006 & 20752.54 & 53 & 12.2 & 126.0 & 92.70 & 2.75 & 4.42 & & RADCIN BARPIER \\
\hline 008 & $20766-68$ & 67 & 10.3 & 126.0 & 81.59 & 2.71 & 5.58 & & RADON BARRIER \\
\hline 008 & $20768-70$ & 69 & 11.3 & 126.0 & 89.52 & 2.71 & 5.75 & & RADON BARFIER \\
\hline 008 & $20770-72$ & 71 & 11.1 & 126.0 & 87.93 & 2.71 & 5.92 & & RADON BARRIER \\
\hline 009 & $207 \quad 78-80$ & 79 & 14.4 & 122.1 & 103.37 & 2.69 & 6.58 & & RADON BARRIER \\
\hline 009 & $20780-82$ & 81 & 13.0 & 12.1 & 93.32 & 2.69 & 6.75 & & RADON BARRIER \\
\hline 009 & $20782-84$ & 83 & 13.2 & 122.1 & 94.75 & 2.69 & $6.9 i$ & & RADON BAFRIER \\
\hline 001 & $2006-8$ & 7 & 9.7 & 125.8 & 77.20 & 2.7 & 0.58 & & RADON PARRIER \\
\hline 001 & $2008-10$ & 9 & 10 & 125.8 & 79.58 & 2.7 & 0.75 & & RADON RARRIER \\
\hline 001 & $208 \quad 10-12$ & 11 & 10.1 & 125.8 & 80.38 & 2.7 & 0.92 & & RADON BARRIER \\
\hline 002 & $208 \quad 12-14$ & 13 & 10.6 & 125.9 & 84.62 & 2.7 & 1.08 & & RADON BARRIER \\
\hline 002 & $208 \quad 14-16$ & 15 & 10.5 & 125.9 & 83.82 & 2.7 & 1.25 & & RADON BARRIER \\
\hline 002 & $20816-18$ & 17 & 10.9 & 125.9 & 87.02 & 2.7 & 1.42 & & RADON BAFRIEK \\
\hline 003 & $20824-30$ & 27 & 11.6 & 121.2 & 78.09 & 2.73 & 2.25 & $2.8 E-06$ & RADON BARRIER \\
\hline 004 & $20830 \cdots 36$ & 33 & 11.8 & 124.2 & 88.45 & 2.71 & 2.75 & & RADON BARRIER \\
\hline 005 & $208 \quad 42-48$ & 45 & 12.3 & 122.2 & 85.22 & 2.73 & 3.75 & & RADON BARAIER \\
\hline 007 & $20860-66$ & 63 & 13 & 123.6 & 95.69 & 2.71 & 5.25 & & RADON BARRIER \\
\hline 009 & $20878-84$ & 81 & 12.7 & 118 & 83.08 & 2.66 & 6.75 & & RADON BARRIER \\
\hline 010 & $208 \quad 84-90$ & 87 & 11.8 & 123.3 & 86.95 & 2.7 & 7.25 & & RADON BARRIER \\
\hline
\end{tabular}

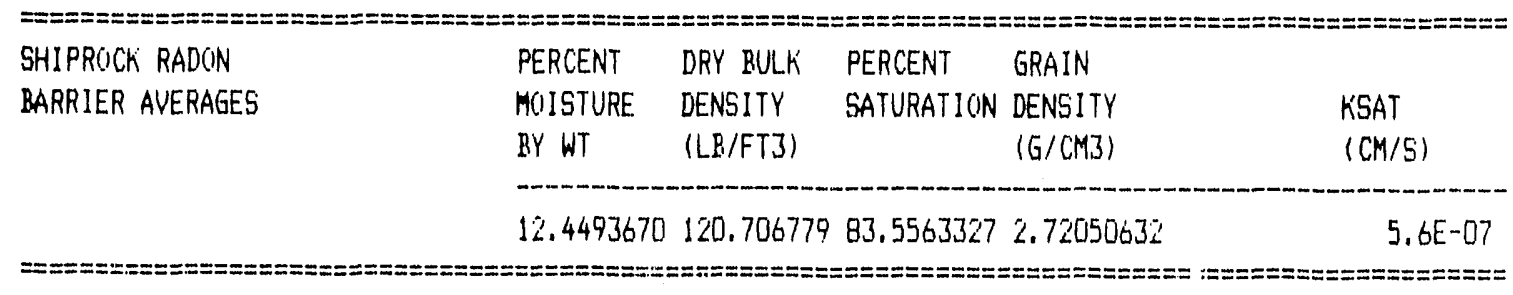


COVER MOISTURE STUDY GEOTECHNICAL DATA (10/31/89)

CLIVE RADON BARRIER DATA:

\begin{tabular}{|c|c|c|c|c|c|c|c|c|c|c|}
\hline $\begin{array}{l}\text { CLIVE } \\
====== \\
\text { SAMPLE } \\
\text { NO. }\end{array}$ & $\begin{array}{l}\text { HOLE } \\
\text { NO. }\end{array}$ & $\begin{array}{l}\text { CLIVE } \\
========: \\
\text { DEPTH } \\
\text { (INCHES) }\end{array}$ & $\begin{array}{l}\text { AVERAGE } \\
\text { depth } \\
\text { (INCHES) }\end{array}$ & $\begin{array}{l}\text { PERCENT } \\
\text { MOISTURE } \\
\text { BY WT }\end{array}$ & $\begin{array}{l}\text { DRY BULK } \\
\text { DENSITY } \\
\text { (LB/FT3) }\end{array}$ & $\begin{array}{l}\text { PERCENT } \\
\text { SATURATION }\end{array}$ & $\begin{array}{l}\text { GRAIN } \\
\text { DENSITY } \\
(\text { G/CMB) }\end{array}$ & $\begin{array}{l}\text { DEPTH } \\
\text { INTO R.R. } \\
\text { (FEET) }\end{array}$ & $\begin{array}{l}\text { KSAT } \\
(C M / S)\end{array}$ & MATERIAL \\
\hline 001 & 003 & $2-6$ & 4 & 15.6 & 110.8 & 78.18 & 2.75 & 0.33 & & RADON BARRIER \\
\hline 003 & 003 & $14-16$ & 15 & 23.3 & 89.5 & 69.85 & 2.75 & 1.25 & & RADON BARRIER \\
\hline 003 & 003 & $16-18$ & 17 & 24.5 & 89.5 & 73.74 & 2.74 & 1.42 & & RADCN BARRIER \\
\hline 004 & 003 & $18-24$ & 21 & 25.2 & 96.8 & 89.26 & 2.76 & 1.75 & $7.9 E-08$ & RADON BARRIER \\
\hline 005 & 003 & $30-36$ & 33 & 20 & 102.3 & 81.63 & 2.74 & 2.75 & & RADON BARRIER \\
\hline 006 & 003 & $42-48$ & 45 & 26.1 & 99.4 & 97.44 & 2.73 & 3.75 & & RADCN BARRIER \\
\hline 011 & 003 & $78-84$ & 81 & 18 & 103.5 & 78.82 & 2.67 & 6.75 & $6.8 E-07$ & RADON BARRIER \\
\hline 012 & 003 & $84-90$ & 97 & 24.5 & 87 & 69.55 & 2.74 & 8.08 & & RADCN BARRIEF \\
\hline 002 & 004 & $6-8$ & 7 & 24.4 & 95.3 & 86.21 & 2.69 & 0.58 & & RADON BARRIER \\
\hline 002 & 004 & $8-10$ & 9 & 24.3 & 95.3 & 85.86 & 2.69 & 0.75 & & RADON BARRIER \\
\hline 002 & 004 & $10-12$ & 11 & 25.4 & 95.3 & 88.46 & 2.72 & 0.92 & & RADCN BARRIER \\
\hline 003 & 004 & $14-16$ & 15 & 22.1 & 99.9 & 85.11 & 2.74 & 1.25 & & RADON BARRIER \\
\hline 003 & 004 & $16-16$ & 17 & 22.1 & 99.9 & 85.11 & 2.74 & 1.42 & & RADON BARRIER \\
\hline 004 & 004 & $18-20$ & 19 & 23.4 & 101 & $9 ? .54$ & 2.74 & 1.58 & & RADIN BARRIFR \\
\hline 004 & 004 & $20-22$ & 21 & 20.8 & 101 & 81.41 & 2.76 & 1.75 & & FADON BARRIER \\
\hline 001 & 005 & $2-4$ & 3 & 26 & 93.9 & 87.57 & 2.72 & 0.25 & & RADON BARRIER \\
\hline 001 & 005 & $4-6$ & 5 & 25 & 93.9 & 84.21 & 2.72 & 0.42 & & RADON BARRIER \\
\hline 002 & 005 & $8-10$ & 9 & 22.4 & 97.8 & 83.26 & 2.71 & 0.75 & & RADON BARRIER \\
\hline 002 & 005 & $10-12$ & 11 & 24.7 & 97.8 & 89.58 & 2.76 & 0.92 & & RADON BARRIER \\
\hline 003 & 005 & $12-14$ & 13 & 30.2 & 90.6 & 93.27 & 2.74 & 1.08 & & RALINN BARRIER \\
\hline 003 & 005 & $14-16$ & 15 & 29 & 90.6 & 90.32 & 2.72 & 1.25 & & RADON BARRIER \\
\hline 003 & 005 & $16-18$ & 17 & 23.2 & 90.6 & 72.56 & 2.71 & 1.42 & & RADON BARRIER \\
\hline 005 & 005 & $24-30$ & 27 & 24.8 & 93.4 & 83.30 & 2.7 & 2.25 & & RADON BARRIEK \\
\hline 006 & 005 & $30-36$ & 33 & 41 & 77.5 & 93.14 & 2.74 & 2.75 & & RADON BARFIEF \\
\hline 008 & 005 & $42-48$ & 45 & 19.4 & 100.9 & 78.21 & 2.7 & 3.75 & & RADON BARRIER \\
\hline 010 & 005 & $54-60$ & 57 & 21.1 & 106.3 & 96.78 & 2.71 & 4.75 & 4. $2 E-08$ & RADON BARRIER \\
\hline 012 & 005 & $66-72$ & 69 & 19.9 & 99.9 & 76.25 & 2.75 & 5.75 & & RADON BARRIER \\
\hline 014 & 005 & $78-84$ & 81 & 25.7 & 94.2 & 86.79 & 2.73 & 6.75 & & RADON BARRIER \\
\hline $00 \%$ & 006 & $8-10$ & 9 & 19.9 & 103.3 & 84.17 & 2.72 & 0.75 & & RADON PARRIER \\
\hline $00 \%$ & 006 & $10-12$ & 11 & 20.1 & 103.3 & 84.54 & 2.73 & 0.92 & & RADON BARRIEF \\
\hline 003 & 006 & $14-16$ & 15 & 18.6 & & 66.71 & 2.75 & 1.25 & & RADON BARFIEF \\
\hline 003 & 006 & $16-16$ & 17 & 19.2 & & 67.91 & 2.78 & 1.42 & & RADON BARRIER \\
\hline
\end{tabular}


COVER MOISTURE STUDY GEOTECHNICAL DATA $110 / 31 / 88)$

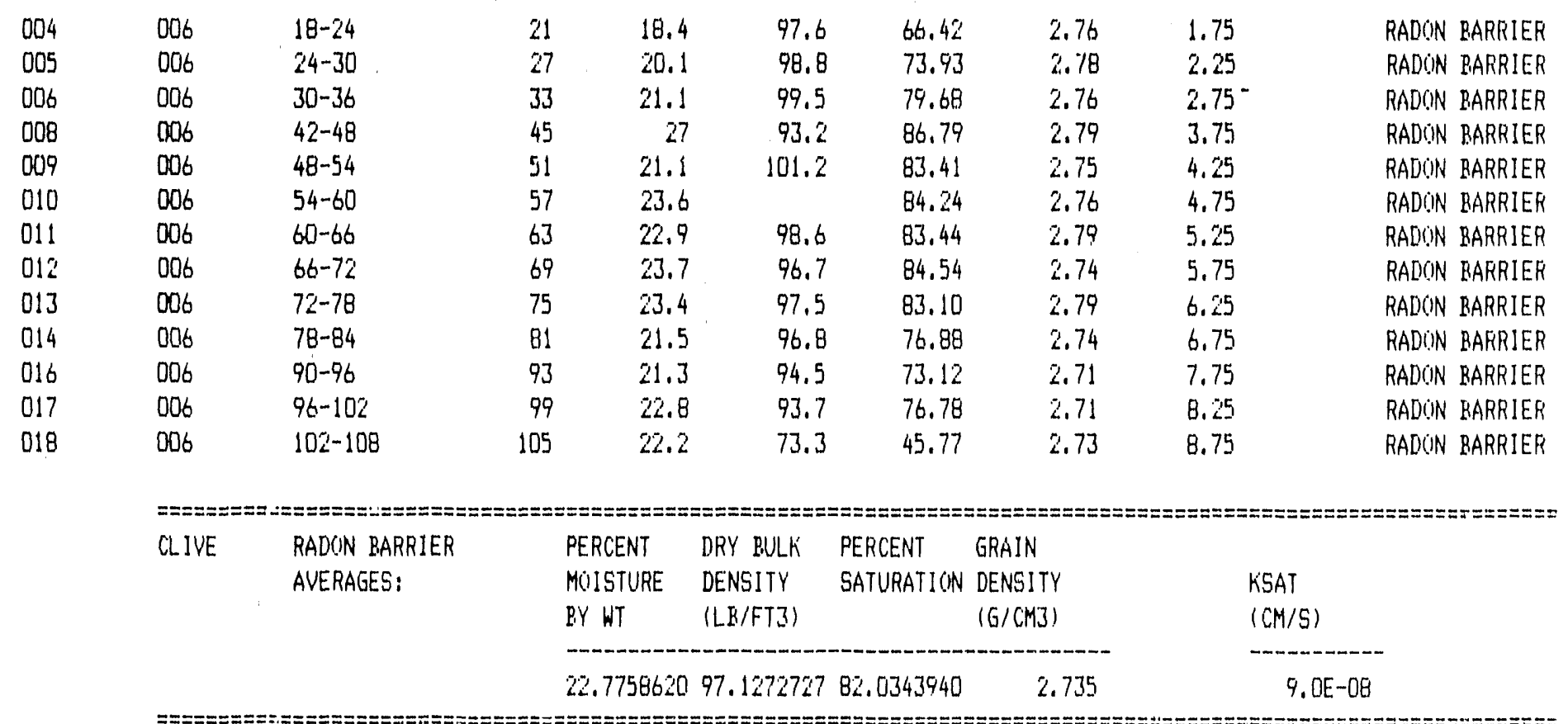

CLIVE TAILINGS DATA:

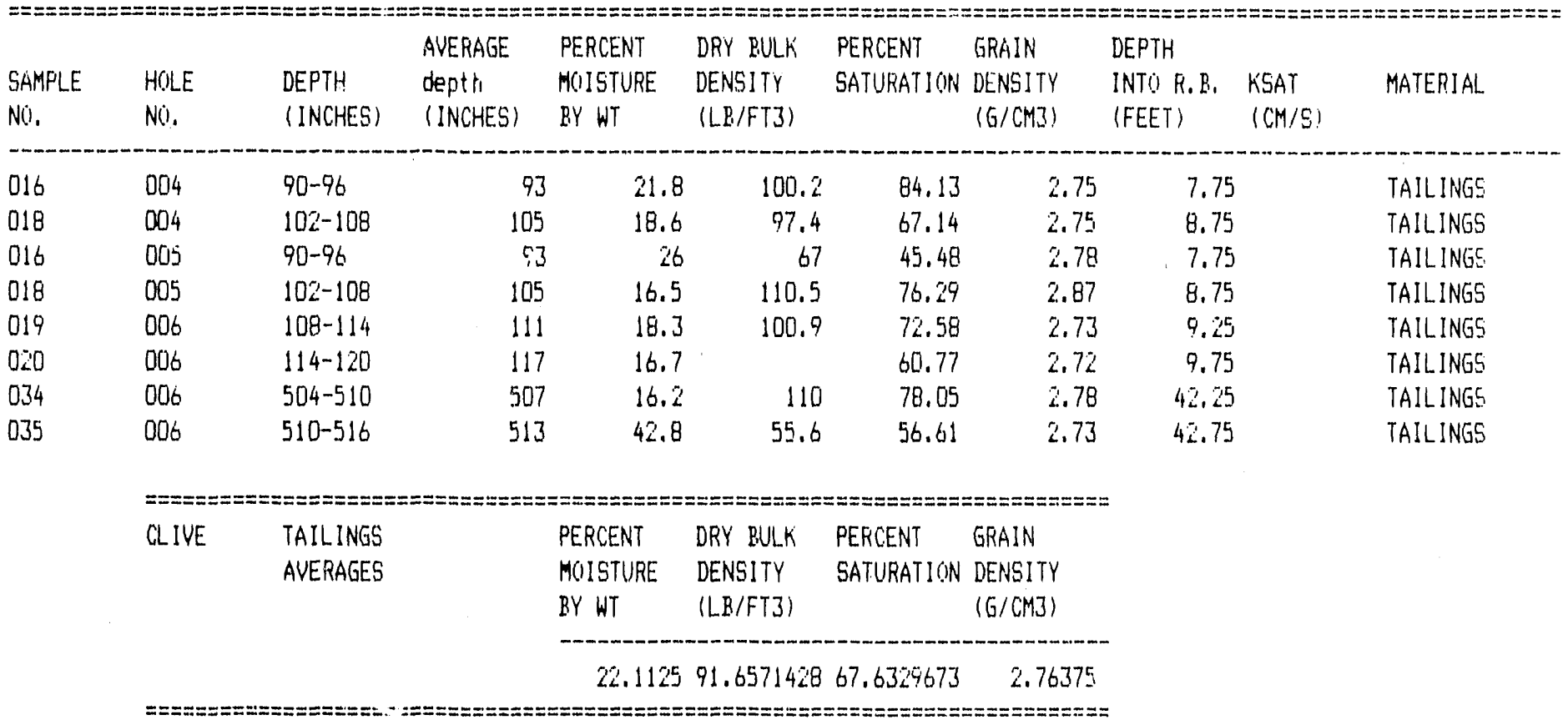


COVER MOISTURE STUDY GEOTECHNICAL DATA (10/31/88)

BURREL RADCN BARRIER DATAI

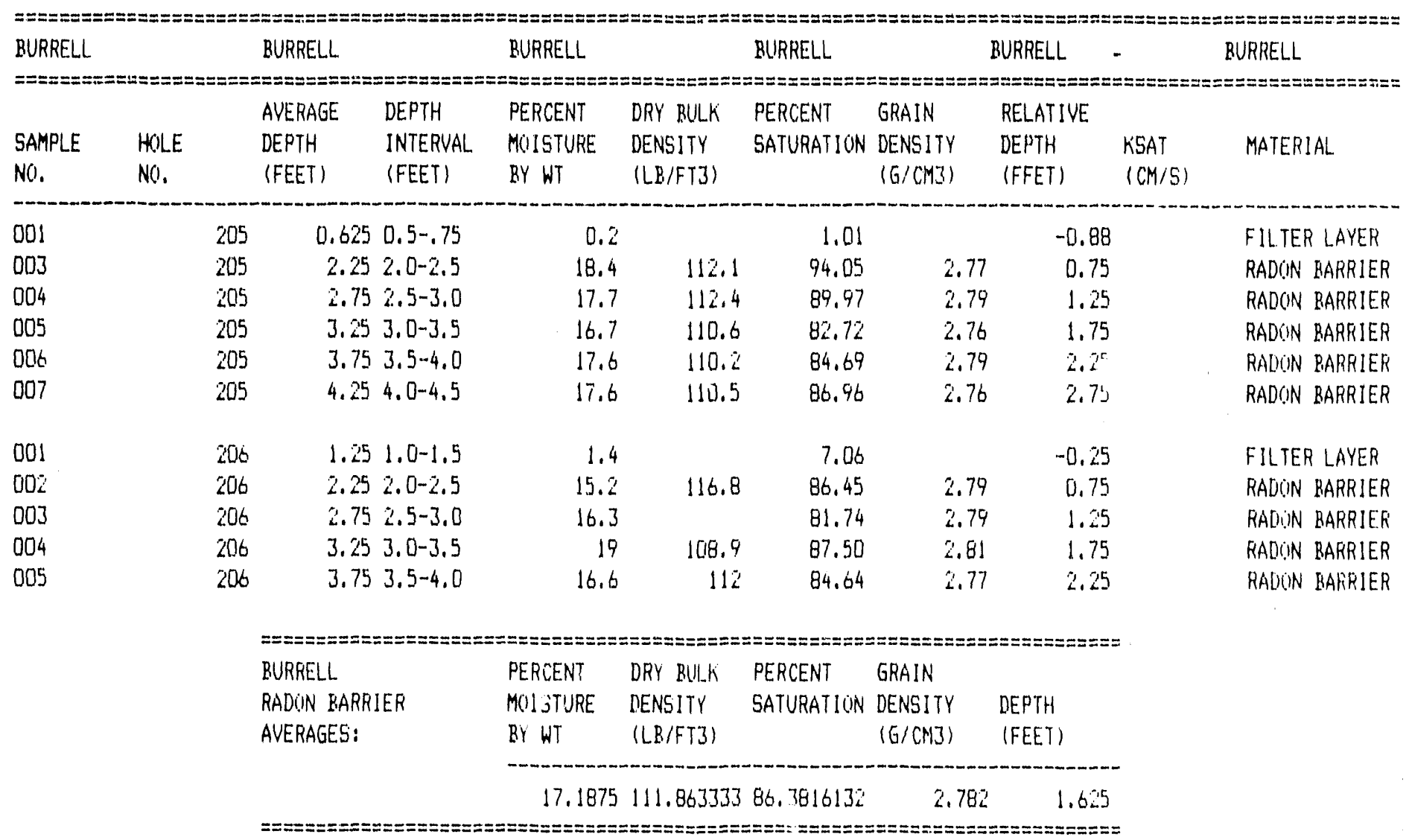




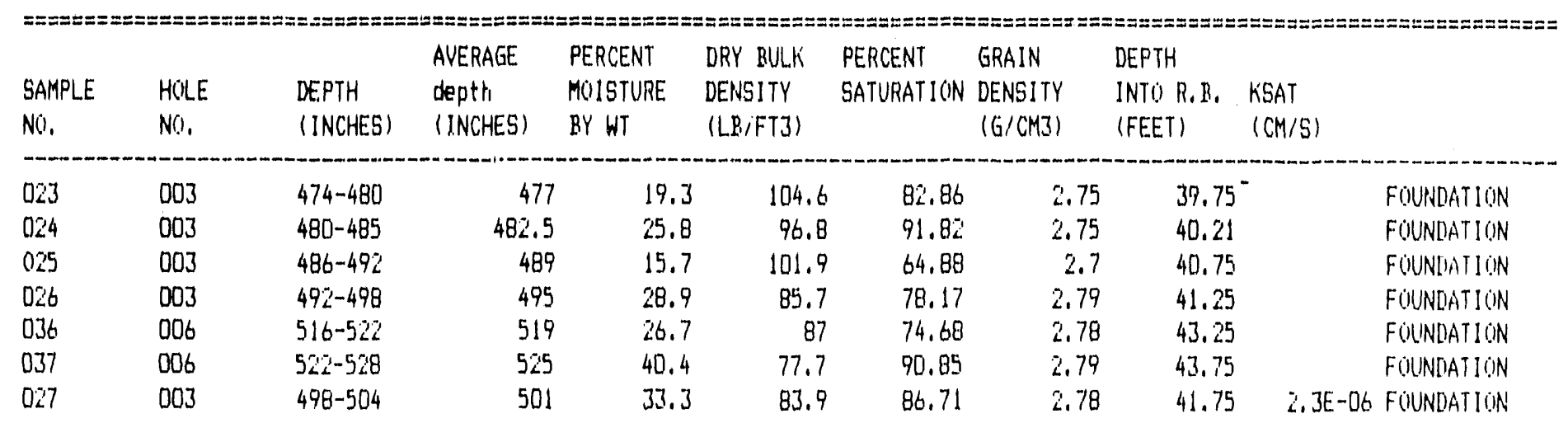

\begin{tabular}{|c|c|c|c|c|c|c|}
\hline CLIVE & $\begin{array}{l}\text { FOIUNDATION } \\
\text { AUERAGES }\end{array}$ & $\begin{array}{l}\text { PERCENT } \\
\text { M()ISTURE } \\
\text { BY WT }\end{array}$ & $\begin{array}{l}\text { DRY BULK } \\
\text { DENSITY } \\
\text { (LB.FT3) }\end{array}$ & $\begin{array}{l}\text { PERCENT } \\
\text { SATURATION }\end{array}$ & $\begin{array}{l}\text { GRAIN } \\
\text { DENSITY } \\
(G / C M I)\end{array}$ & $\begin{array}{l}\text { KSAT } \\
\text { (CM/S) }\end{array}$ \\
\hline & & $27.15714 \%$ & 91.085714 & 81.4247381 & $\therefore .76 \% 85714$ & 2. $3 E-06$ \\
\hline
\end{tabular}



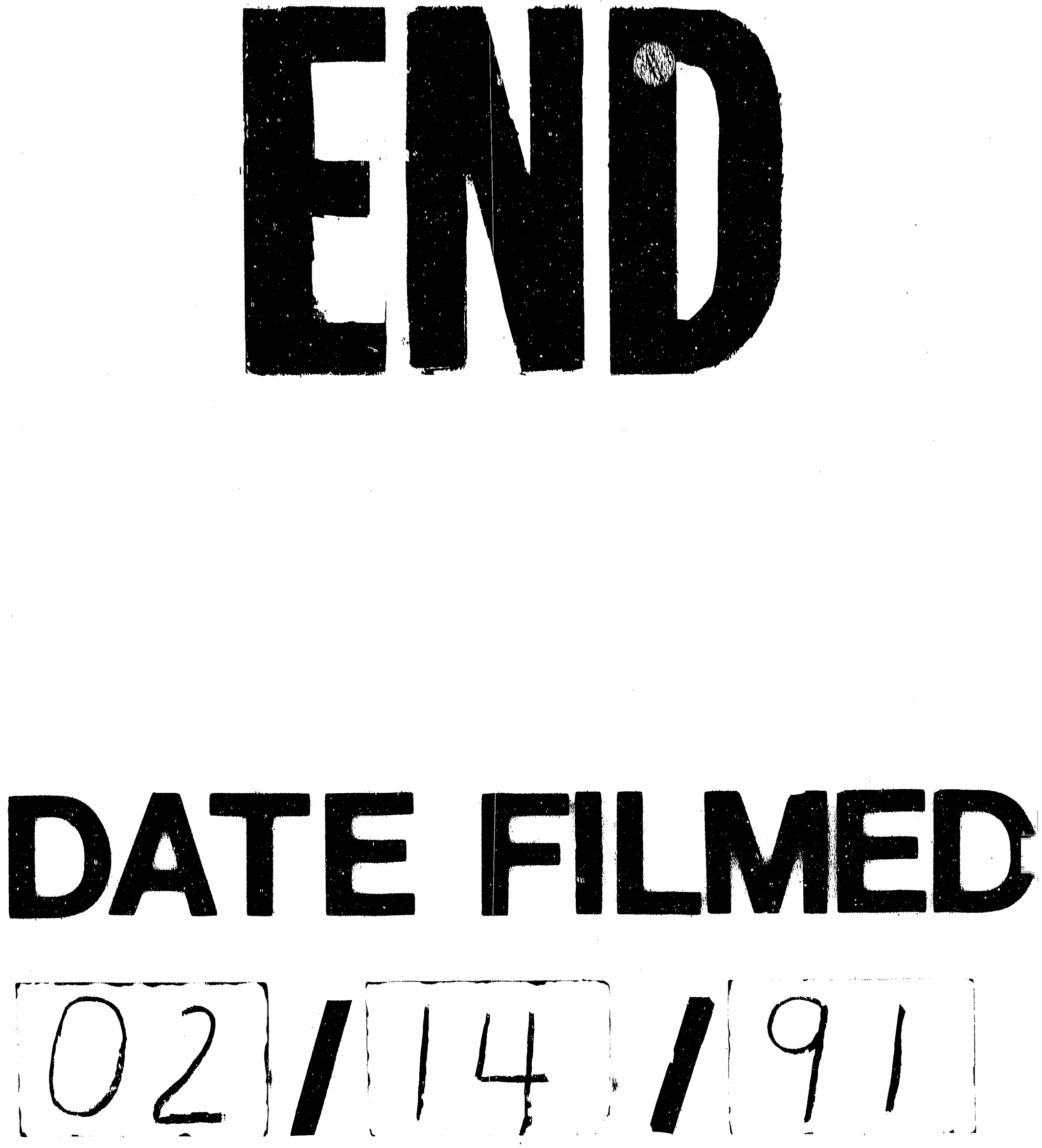
